\title{
Redressing Wounds: Finding a Legal Framework to Remedy Racial Disparities in Medical Care
}

\author{
Michael S. Shin $\dagger$
}

TABLE OF CONTENTS

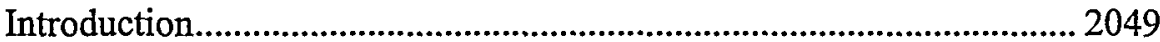

I. Racial and Ethnic Inequalities in Medical Care ............................. 2052

A. Racial Differences in Health Status ......................................... 2053

B. Racial Differences in Medical Treatment ............................... 2054

1. Evidence of Racial Differences in Medical Treatment ...... 2055

a. Surgery and Medical Procedures .................................. 2056

b. Pain Treatment and Outpatient Care............................ 2057

2. Possible Socioeconomic and Demographic Causes of

Disparities in Medical Treatment..................................... 2058

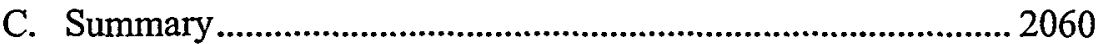

II. The Psychology of Medical Decision Making ................................. 2060

A. Psychological Variables that May Contribute to Racial

Disparities in Medical Treatment .......................................... 2061

B. Cognitive Bias in Medical Decision Making............................ 2064

I. The Nature of Modern Bias............................................... 2064

a. Implicit Attitudes ........................................................2065

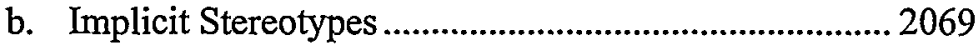

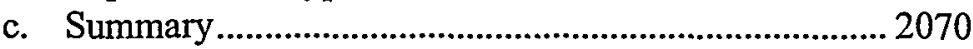

2. The Effects of Cognitive Bias in the Clinical Setting ......... 2071

a. The Potential Effects of Implicit Attitudes on the Patient-Caregiver Relationship .................................... 2071

Copyright $(92002$ California Law Review, Inc. California Law Review, Inc. (CLR) is a California nonprofit corporation. CLR and the authors are solely responsible for the content of their publications.

$\dagger$ J.D. Candidate, School of Law, University of California, Berkeley (Boalt Hall), 2003. I would like to thank Professor Linda Krieger for leading me to the topic for this Comment and for her guidance during the writing process. I am grateful to Chris Hazuka and Jen Conners for doing a fantastic editing job and also thank all the other members of the California Law Review, particularly Michelle Anderson, Michelle Armond, Amy DeVaudreuil, Peter Leckman, and Janet Tung, who contributed to the editing process. Finally, I want to thank my wife, Emily, and my family for their love and support. 
b. The Potential Effects of Implicit Stereotypes on Medical Decision Making......................................... 2072

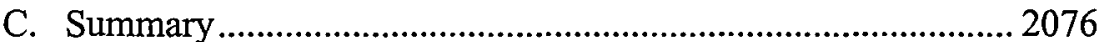

III. Existing Legal Safeguards that Might Be Used to Protect Against Discrimination in Medical Care.....................................2076

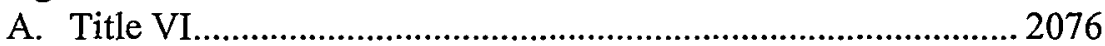

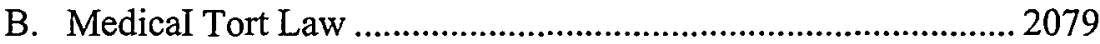

C. The Emergency Medical Treatment and Active Labor

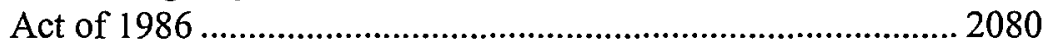

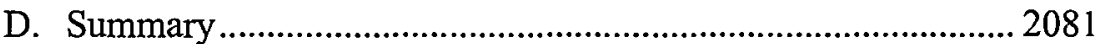

IV. Finding the Proper Legal Framework ......................................... 2081

A. Title VII as a Guiding Framework ............................................ 2083

1. Title VII's Disparate-Treatment Models........................... 2083

2. Application of the Models to Cases Involving Implicit

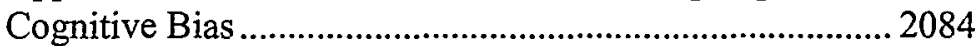

a. The Role of Discriminatory Intent in Title VII Cases . 2084

b. The "Direct" Evidence Requirement ........................... 2086

c. Implications for Claims Stemming from

Unconscious Discrimination...................................... 2089

B. The Age Discrimination in Employment Act ..........................2090

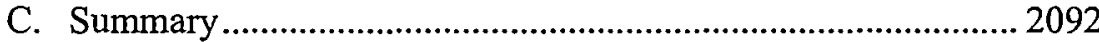

V. Conclusions and Recommendations............................................ 2092 


\title{
Redressing Wounds: Finding a Legal Framework to Remedy Racial Disparities in Medical Care
}

\author{
Michael S. Shin
}

In recent years, numerous medical studies and reports have documented startling disparities between the health status of African Americans and White Americans. The literature is replete with evidence that one of the main causes of these racial disparities is the differential treatment of patients of different racial groups. This Comment addresses the possibility that implicit cognitive bias, in the form of implicit attitudes and stereotypes, significantly contributes to these racial disparities in medical treatment. Finding existing legal frameworks inadequate to address current disparities in health care, this Comment recommends avenues for the reworking of Title VI of the Civil Rights Act of 1964. Specifically, it suggests that disparate-treatment provisions that encompass claims arising from unintentional discrimination should be incorporated into Title VI, and it offers the employment law frameworks of Title VII and the Age Discrimination in Employment Act as models for such reform.

\section{INTRODUCTION}

In 1937, blues legend Bessie Smith was driving in Mississippi when the car in which she was riding rear-ended a slow moving truck and rolled over, crushing hor left arm and breaking her ribs. ${ }^{1}$ She was left lying on the road, bleeding from her injuries. ${ }^{2}$ Her son, Jack Gee, Jr., later discussed his mother's death in the following account: ${ }^{3}$

We have never found out accurately yet how my mother was taken back to town, but we do know that she was first taken to a white hospital, which refused to administer first aid or take her in. She was then taken to the Afro-American Hospital, a colored institution. This hospital didn't have the proper equipment with which to operate. Physicians had to run all over town to get the proper equipment. It was about 11:30 A.M. before they

1. THE Red Hot JAZz ARChive, Bessie SMITH, at http://www.redhotjazz.com/bessie.html (last visited Mar. 18, 2002).

2. Id.

3. Gee's account became the subject of a 1959 Edward Albee play. See EDwARD AlbeE, THE Death of Bessie SMith (1959). 
administered ether to her. She died at 11:45 A.M. No reason was given as to why she died, but we know clearly that she died from loss of blood and neglect. ${ }^{4}$

On April 1, 1950, Dr. Charles Drew, the Howard University professor who developed the process for preserving blood as plasma and started the first blood bank, was driving to a medical conference in Tuskegee, Alabama, when his car struck the soft shoulder of the road and flipped. ${ }^{5}$ Drew, severely injured, was rushed to a nearby hospital in Burlington, North Carolina, but died later that night. ${ }^{6}$ Rumors quickly spread about Drew's death. According to a number of accounts, Drew died because the hospital to which he was taken did not admit African American patients. ${ }^{7}$ It appears that Drew, founder of the American Red Cross Blood Bank, may have bled to death because the doctors at the hospital refused to give him a blood transfusion. ${ }^{8}$

Although historians have since debated the circumstances surrounding both Smith's and Drew's deaths, ${ }^{9}$ the stories nevertheless call attention to the tainted racial history of the American health care system. ${ }^{10}$ In the postslavery era, hospitals in some of the northern states and throughout the South openly practiced segregation, with Jim Crow laws barring African Americans from the "White" health care system." The few hospitals that were not "White only" admitted only limited numbers of African Americans, restricted those that they admitted to "Colored" floors, and sorted sheets, gowns, and thermometers separately as "White" or "Colored."12 And since most medical schools refused to admit African Americans, hospitals for African Americans suffered from a shortage of doctors in addition to a lack of technology and basic facilities. ${ }^{13}$ To make matters worse, the federal government endorsed segregation within the health care system by providing federal Hill-Burton Act grants for the

4. Debra Spencer, Is Racism Killing Us?, EsSENCE, Jan. 1993, at 32.

5. The Afro-American Almanac, Charles Drew, at http://www.toptags.com/aama/bio/men/ cdrew.htm (last updated Feb. 2001).

6. Id.

7. Id.

8. Id.

9. See Charlene Drew Jarvis, Close to Home, WASH. Post, Feb. 13, 1994, at C8 (stating that a compassionate team of physicians treated her father promptly, giving him at least one blood transfusion, but he nonetheless died due to the severity of his injuries); Ross Whitney, Reflections of 1920 's and 30's Street Life in the Music of Bessie Smith, in BluesNet Readings (1995), at http://bluesnet.hub.org/readings/bessie.html (claiming that Gee's account was based entirely on rumor).

10. See Sidney D. Watson, Race, Ethnicity and Quality of Care: Inequalities and Incentives, 27 AM. J.L. \& MED. 203, 210-11 (2001).

11. Id.

12. Id.

13. Id. 
construction and expansion of "separate hospitals for separate population groups." 14

Overt racial segregation in health care ended with the passage of Title VI of the Civil Rights Act of $1964 .{ }^{15}$ Title VI conditions the receipt of federal funds for programs such as Medicaid and Medicare on the prohibition of racial discrimination in the programs. Title VI immediately impacted the racial landscape of the American health care system: ${ }^{16}$ by July 1, 1966, the startup date for Medicare, more than six-thousand-five-hundred hospitalsover $92 \%$ of hospitals at the time-had become integrated in compliance with Title VI. ${ }^{17}$

While on the surface racial dynamics within the American health care system drastically changed during the last half of the twentieth century, vestiges of segregated health care remain, particularly in the form of racial disparities in both health status and treatment. ${ }^{18}$ Thus, while an African American in need of medical care will not be turned away from a hospital today explicitly on the basis of race, what happens once he or she is admitted is another question altogether. It is clear that African Americans and Whites do not fare equally well in the American health care system: many studies have documented significant racial disparities in health care, including differences in medical outcomes, ${ }^{19}$ as well as in the treatment received in a wide variety of clinical areas. ${ }^{20}$ It is less clear, however, what accounts for these disparities. Certainly a multitude of factors lead to racial disparities in medical treatment and outcomes. These factors include socioeconomic and demographic variables as well as differences in levels of access to the health care system. ${ }^{21}$ Similarly, differences in external factors, such as the type of a patient's insurance coverage or the severity of a patient's medical condition, may contribute to racial disparities in the health care system. ${ }^{22}$

In this Comment, I approach the problem of racial disparities in medical care from a psychological perspective. Several recent studies indicate that even when external factors such as insurance coverage and severity of disease are controlled for, racial disparities in medical treatment persist. ${ }^{23}$ And there is growing empirical evidence that this residual difference stems, at least in part, from differential treatment by treating physicians based on

14. Id. (referring to 42 U.S.C. $\S 291 \mathrm{e}(\mathrm{f})(2000))$.

15. 42 U.S.C. $\$ 2000 d(2000)$.

16. See David B. Smith, Health Care Divided: Race and Healing a Nation 155 (1999).

17. See Watson, supra note 10 , at 215 .

18. See infra Parts I.A \& I.B.

19. See infra notes $27-40$ and accompanying text.

20. See infra notes 47-75 and accompanying text.

21. See discussion infra Part I.B.2.

22. See id.

23. See infra notes $\mathbf{7 8 - 8 6}$ and accompanying text. 
the race of the patients. ${ }^{24}$ Using this evidence as a starting point, I explore the possibility that doctors' implicit cognitive biases, in the form of negative nonconscious attitudes and stereotypes, ${ }^{25}$ act as significant causal factors contributing to racial disparities in medical treatment. I then examine the adequacy of existing legal frameworks to counteract such unintentional discrimination.

This Comment proceeds in five Parts. Part I reviews literature that documents racial disparities in health status and medical treatment and examines several potential external variables that might account for such disparities. Part II considers psychological mechanisins that might explain racial disparities in status and treatment, focusing on recent psychological theories of cognitive bias in the form of implicit attitudes and implicit stereotypes. Part III examines Title VI of the Civil Rights Act of 1964 and other existing legal safeguards against discrimination and finds them inadequate to address current racial disparities in health care. Part IV turns to Title VII of the Civil Rights Act of 1964 and the Age Discrimination in Employment Act ("ADEA") in search of a possible statutory model to address the problem of disparate treatment caused by implicit bias. Finally, using the discussion of Title VII and the ADEA as a starting point, Part V recommends several avenues for reform.

I

Racial and Ethnic Inequalities in Medical Care

This Part begins with a discussion of the data that demonstrate racial disparities in health care and then explores the recent attempts to discern the causes of these disparities. It concludes that while the reasons for such disparities in medical care are varied, studies consistently find that disparities persist even when controlling for external factors, such as socioeconomic status and level of insurance coverage. This leaves open the possibility that physicians' personal preferences and underlying cognitive biases are among the factors that lead to differential medical care across racial groups. ${ }^{26} \mathrm{~A}$ discussion of this possibility follows in Part II.

24. M. Gregg Bloche, Race and Discretion in American Medicine, 1 Yale J. Health, Pol'y L. \& Eтнics 95, 103-07 (2001).

25. This Comment uses the terms "implicit," "nonconscious," and "unconscious" to describe attitudes and beliefs that operate below the level of conscious awareness. The use of these terms in this Comment is not meant to imply any connection to the use of such terms in Frcudian psychodynamic theory.

26. See Watson, supra note 10 , at 209. 


\section{A. Racial Differences in Health Status}

A substantial body of scientific literature indicates that a patient's race affects the type and quality of the medical care he or she receives. ${ }^{27}$ In recent years, many studies and reports have uncovered racial differences in health status, access to services, and health outcomes. ${ }^{28}$ The most comprehensive investigation and analysis of comparative health among racial groups took place in 1984, when the Secretary of the Department of Health and Human Services ("DHHS") established the Task Force on Black and Minority Heath ("Task Force") to examine the health status of minority groups within the United States. ${ }^{29}$ The DHHS established the Task Force in response to growing concern about racial disparities in medical health status. ${ }^{30}$ At the time of the Task Force's establishment, while national statistics indicated continuing improvement in health for Americans as a whole, increases in health status were much lower for racial minority groups than they were for Whites. ${ }^{31}$ The Task Force report (released in 1985) revealed significant differences in key health indicators among racial groups within the United States. ${ }^{32}$ The Task Force analyzed national mortality data for more than forty disease categories from 1979 to $1981 . .^{33}$ For each category, the Task Force calculated the number of "excess deaths," which it defined as the difference between the death rates observed in the minority population and the corresponding age- and sex-specific death rates in the White population. ${ }^{34}$ The Task Force reported that sixtythousand excess deaths occurred each year in the minority populations. ${ }^{35}$

More recent statistics indicate that the gap between the health status of minorities and Whites continues to exist. For instance, African Americans, Latinos, and Native Americans all have higher average mortality rates than

27. See generally Morehouse Medical Treatment and Effectiveness Center, A Synthesis of the Literature: Racial and Ethnic Differences in Access to Medical Care (Oct. 1999), available at http://www.kff.org/content/1999/19991014a/ [hereinafter SYNTHESIs].

28. See generally INstitute of Medicine, Unequal Treatment: Confronting Racial and Ethnic Disparities in Health Care (2002) [hereinafter Unequal TreatMient]; Synthesis, supra note 27 (reviewing medical studies on racial and ethnic differences in health and health services from 1985 to 1999).

29. U.S. Dep't of Health \& Human Servs., Report of the Secretary's Task Force on Black and Minority Health, Volume I: Executive Summary (1985).

30. See SYNTHESIS, supra note 27 , at 5.

31. Id.

32. Id.

33. Id.

34. Centers for Disease Control, Perspectives in Disease Prevention and Health Promotion Report of the Secretary's Task Force on Black and Minority Health, 35 MORBIDITY \& MoRTALITY WKLY. REP. 109, 110 (1986) [hereinafter Perspectives]; see also SYNTHEsIs, supra note 27, at 5-6.

35. Six causes of death-cancer, cardiovascular disease and stroke, cirrhosis, diabetes, homicide and accidents, and infant mortality-accounted for more than $80 \%$ of the excess mortality. Perspectives, supra note 34, at 110-11. 
Whites for each age until forty-four years of age. ${ }^{36}$ Moreover, differences in mortality rates for African Americans and Whites persist when overall mortality is examined by a measure of socioeconomic conditions, such as income. ${ }^{37}$ Infant mortality rates, which are considered among the most sensitive indicators of the health and well-being of populations, ${ }^{38}$ are twice as high among African American infants as White infants, even when analyzed by a measure of socioeconomic conditions, such as the mother's educational level. ${ }^{39}$ Subjective indicies of health reflect these disparities: African Americans are more likely than Whites of similar incomes to rate their health as fair or poor. ${ }^{40}$

\section{B. Racial Differences in Medical Treatment}

The root causes of racial disparities in health care status have been exceedingly difficult to isolate. The DHHS Task Force attributed the disparities to "the interaction of physiological, cultural, psychological, and societal factors that are poorly understood for the general population and even less so for minorities." 41 While the Task Force's report examined some possible causes, including minority groups' ability to access and utilize the health care system ${ }^{42}$ its main purpose was merely to document the disparities in health status. Thus, the report shed little light on the underlying causes of those disparities. ${ }^{43}$

In recent years, a number of studies have explored in greater depth the possible causes of racial disparities in health status. For instance, some have followed up on the Task Force Report's documentation of racial disparities in access to medical care, providing more detailed evidence of racial disparities in insurance coverage and access to primary care. ${ }^{44}$ This in turn has led some to question, for example, whether underlying

36. U.S. Dep't of Health \& Human Servs., Nat'l Ctr. For Health Statistics, Health, United States, 1998 with Socloeconomic Status and Health Chartbook 50, 92-96 (1998), available at http://www.cdc.gov/nchs/data/hus/hus98.pdf [hcreinafter HEALTH].

37. See, e.g., Gregory Pappas et al., The Increasing Disparity in Mortality Between Socioeconomic Groups in the United States, 1960 and 1986, 329 NEW ENG. J. MED. 103 (1993).

38. See Henry J. Kaiser Family Found., Key Facts: Race, Ethnicity \& Medical Care 16 (1999), at http://www.kff.org/content/1999/19991014a/ [hereinafter KEY FACTs].

39. See HeAlTh, supra note 36 , at 50.

40. Id. However, the disparity is smaller between those with higher incomes than between those with lower incomes. Id.

41. Id. at 5 .

42. Id. The report noted that even though Medicaid and Medicare programs were increasing access and utilization of medical services for minority groups, minority racial and ethnic groups continued to have poorer access to quality health care services than Whites. Id.

43. Id.

44. See KEY FACTS, supra note 38 (reporting that minority Americans are at least twice as likely to be uninsured as Whites and that minority Medicare beneficiaries are far more likely than Whites to rely solely on the traditional Medicare program for insurance protection); see also KAISER COMM'N ON Medicaid and the Uninsured, Medicaid Today: A Profile of the LoW-INCOME UNINSUREd 5 (1999), available at http://ww.kff.org/content1999/2158/lowincomeunins.pdf. 
institutional policies that are "race-neutral" on their face might actually result in disparate levels of access. ${ }^{45}$ Other studies have explored the possibility that racial disparities in health status stem from biological differences, such as genetic differences that influence responses to pharmacologic and other therapeutic treatments. ${ }^{46}$ Some researchers have taken another path, looking in depth at a more direct source of racial disparities in health status: differences in treatment and in the utilization of medical procedures across racial groups.

\section{Evidence of Racial Differences in Medical Treatment}

Medical literature is replete with studies reporting racial disparities in medical treatment. ${ }^{47}$ Studies have shown, for example, that there are significant differences in the preventative services and therapeutic treatment that African Americans and White Americans receive for heart disease, ${ }^{48}$ breast cancer, ${ }^{49}$ lung cancer, ${ }^{50}$ liver disease, ${ }^{51}$ and HIV-AIDS. ${ }^{52}$ Additionally, there is a substantial body of literature that reports significant racial disparities in the general treatment of pain..$^{53}$

45. For instance, many hospitals restrict access by admitting only patients who are being treated by a physician with admitting privileges at the particular hospital. See Sidney D. Watson, Reinvigorating Title V7: Defending Health Care Discrimination-It Shouldn't Be So Easy, 58 FoRdHAM L. Rev. 939, 941 (1990). Other hospitals require substantial deposits prior to admission for in-patient treatment. Id. at 942 . Additionally, a number of health care facilities limit the number of Medicaid patients that they will admit and many hospitals create language barriers by failing to provide interpreters or translators. Id. Given that a disproportionate number of patients who cannot meet such access requirements are members of racial or ethnic minority groups, these common policies effectively serve as racial and ethnic barriers to access. Id. Additionally, as one study noted, "institutional policy forces geared toward promoting cost-effectiveness and efficient care may disproportionately affect minority patients." UNEQUAL TREATMENT, supra note 28, at 102.

46. Id. at 111 .

47. See generally SYNTHESIS, supra note 27, at 6-18.

48. See, e.g., Richard F. Gillum et al., Coronary Revascularization and Cardiac Catherization in the United States: Trends in Racial Differences, 29 J. AM. C. CARDroLOGY 1557 (1997).

49. See, e.g., Marian E. Gornick et al., Effects of Race and Income on Mortality and Use of Services Among Medicare Beneficiaries, 335 NEw ENG. J. MED. 791 (1996) (finding that elderly African American women are less likely than their White peers to have had a mammogram despite Medicare reimbursement for the service).

50. See, e.g., Peter B. Bach et al., Racial Differences in the Treatment of Early-Stage Lung Cancer, 341 NEw ENG. J. MED. 1198 (1999) (finding that the lower survival rate among African American patients with early-stage, non-small-cell lung cancer, as compared with White patients, is largely explained by the lower rate of surgical treatment among African Americans).

51. See, e.g., G. Caleb Alexander et al., Barriers to Cadaveric Renal Transplantation Among Blacks, Women, and the Poor, 280 J. AM. MED. Ass'N 1148 (1998).

52. See, e.g., Martin F. Shapiro et al., Variations in the Care of HIV-Infected Adults in the United States: Results from the HIV Cost and Services Utilization Study, 281 J. Am. MEd. Ass'N 2305 (1999) (finding that African Americans were more than twice as likely as Whites to not receive combination drug therapy and 1.5 times more likely than Whites to not get preventative treatment for pneumocystic carinii pneumonia, a common infection for HIV patients).

53. See infra notes $67-71$ and accompanying text. 


\section{a. Surgery and Medical Procedures}

African Americans receive only three-fourths of the high-technology interventions prescribed for Whites and are more likely to be discharged in an unstable condition..$^{54}$ Hospitalization and death rates are higher among elderly African Americans than elderly Whites. ${ }^{55}$ When hospitalized, African Americans receive fewer surgical interventions, diagnostic tests, medical services, and less optimal interventions than Whites-even when their diagnoses, symptoms, and source of payment are the same.${ }^{56}$ And this disparity exists across a number of different types of medical services: cardiology and cardiac surgery, obstetrics, general medicine, kidney transplants, hip replacements, inammograms, oncology, and leg-sparing surgery for peripheral vascular disease. ${ }^{57}$

Despite higher rates of heart disease in African Americans, Whites are twice as likely to undergo coronary angioplasty and coronary bypass surgery. ${ }^{58}$ Doctors are more likely to dismiss the use of cardiopulmonary resuscitation as a treatment option for African Americans, Asians, and Hispanics than they are for Whites. ${ }^{59}$ Whites on dialysis are two-thirds more likely to receive a kidney transplant than non-Whites. ${ }^{60}$ White males from twenty-five to forty-four years of age are the inost frequent recipients of long-term hemodialysis. ${ }^{61}$ Whites are $5 \%$ to $15 \%$ more likely to receive aggressive treatment. ${ }^{62}$ African Americans with HIV are less likely than Whites to receive drug therapies used to prevent pneumonia, a major killer

54. Watson, supra note 10 , at 207.

55. Carol Stevens, System, Race and Suspicion Promote Medical Disparities, Det. NEws, Dec. 10, 1995, at A11.

56. Watson, supra note 10 , at 205.

57. Id. at 206.

58. See Synthesis, supra note 27, at 6-9; see also Council on Ethical and Judicial Affairs, BlackWhite Disparities in Health Care, 263 J. AM. MED. Ass'N 2344, 2344-45 (1990); Albert Oberman \& Gary Cutter, Issues in the Natural History and Treatment of Coronary Heart Disease in Black Populations: Surgical Treatment, 108 Am. HearT J. 688, 688-94 (1984) (discussing the results of a study that showed a preferential selection of Whites for coronary artery bypass grafting); Mark B. Wenneker \& Amold M. Epstein, Racial Inequalities in the Use of Procedures for Patients with Ischemic Heart Disease in Massachusetts, 261 J. AM. MED. Ass'N 253 (1989); cf. Charlcs Maynard et al., Blacks in the Coronary Artery Surgery Study (CASS): Race and Clinical Decision Making, 76 AM. J. Pub. Health 1446, 1446-48 (1986) (finding that differences in clinical or angiographic characteristics could not explain the rate of bypass surgery).

59. Stevens, supra note 55.

60. Id.; see also Paul W. Eggers, Effect of Transplantation on the Medicare End-Stage Renal Disease Program, 318 NEw ENG. J. MED. 223, 229 (1988) (reporting that while African Americans accounted for $33 \%$ of patients with end-stage renal problcms, they represented only $21 \%$ of the patients who received kidney transplants); C.M. Kjellstrand, Age, Sex, and Race Inequality in Renal Transplantation, 148 ARCHIVEs INTERNAL MED. 1305, 1307 (1988).

61. Stevens, supra note 55.

62. Council on Ethical and Judicial Affairs, Black-White Disparities in Health Care, $263 \mathrm{~J}$. AM. MED. Ass'N 2344, 2345 (1990); see also Carl M. Kjellstrand \& George M. Logan, Racial, Sexual and Age Inequalities in Chronic Dialysis, 45 NePHRon 257, 260 (1987) ("In 3 of 4 categories, blacks received less dialysis than whites."). 
of HIV-infected people. ${ }^{63}$ When hospitalized with pneumonia, African Americans were less likely than Whites to receive intensive care. ${ }^{64}$

\section{b. Pain Treatment and Outpatient Care}

As noted above, recent studies have shown that doctors are less likely to prescribe antidepressants for major depression ${ }^{65}$ or antiretroviral therapy for HIV infection ${ }^{66}$ to African Americans. Moreover, while it is widely recognized that, generally speaking, pain is undertreated within the American health systein, ${ }^{67}$ there is growing evidence that the undertreatment of pain is more severe for minority patients than it is for White patients.

In a recent study of access to analgesics,${ }^{68}$ researchers reviewed emergency room records for a forty-month period at an emergency room in Atlanta and reported that African American patients were significantly less likely than White patients to receive analgesics for long bone fractures despite similar records of complaints about pain in the medical reports. ${ }^{69} \mathrm{An}$ other study examined differences in the treatment of pain across heath care facilities, comparing minority and nonminority community-treatment settings. $^{70}$ The researchers concluded that "[p]atients who were treated at centers that primarily saw African American persons, Hispanic persons, or both and patients who were treated at university centers were more likely to receive inadequate analgesia than were those who received treatment in nonminority community treatment settings." $" 71$

While there is less known about access to medical care and treatinent for other racial and ethnic minority groups, the few available studies confirm that Hispanic and Native Americans suffer from similar treatment disparities. ${ }^{72}$ Both Hispanic and Native Americans are significantly less likely

63. See Shapiro, supra note 52.

64. Council on Ethical and Judicial Affairs, supra note 62, at 2345; see also John Yergan, Relationship Between Patient Race and the Intensity of Hospital Services, 25 MED. CARE 592, 600, 603 (1987) (suggesting that non-White pneumonic patients receive fewer services, especially with regard to intensive care).

65. See Jo Anne Sirey, Predictors of Antidepressant Prescription and Early Use Among Depressed Outpatients, 156 AM. J. PsychIATRY 690, 690 (1999).

66. See Richard D. Moore, Racial Differences in the Use of Drug Therapy for HIV Disease in an Urban Community, 330 New ENG. J. MEd. 763, 763 (1994).

67. See Barry R. Furrow, Pain Management and Provider Liability: No More Excuses, 29 J.L. MED. \& ETHICs 28, 28 (2001) ("Pain is undertreatcd in the American health-care system at all levels: physician offices, hospitals, long-term care facilities."); Richard M. Marks \& Edward J. Sachar, Undertreatment of Medical Inpatients with Narcotic Analgesics, 78 ANNALs INTERNAL MED. 173 (1973).

68. K.H. Todd et al., Ethnicity and Analgesic Practice, 35 AnNals EMERgency MED. 11 (2000).

69. Id. at 14-15.

70. See Charles S. Cleeland et al., Pain and Treatment of Pain in Minority Patients with Cancer, 127 ANNALS INTERNAL MED. 813, 813 (1997).

71. Id. at $\$ 14$.

72. Watson, supra note 10 , at 208. 
than Whites to receive cardiac bypass surgery and angioplasty, ${ }^{73}$ and Hispanics are less likely to receive other major therapeutic procedures. ${ }^{74}$ Hispanics are also less likely to get adequate treatment for cancer-related pain and are twice as likely as White patients to receive no pain medication when treated in the emergency room for bone fractures. ${ }^{75}$

\section{Possible Socioeconomic and Demographic Causes of Disparities in Medical Treatment}

A number of recent studies have attempted to isolate the causes of racial disparities in medical treatment by controlling for possible confounding variables. For example, several studies have shown that differences in the patient's insurance coverage or in the severity of his or her disease contribute to racial disparities. ${ }^{76}$ And there is no dearth of candidates for other contributing causes of racial disparities in medical treatment. As one set of researchers examining racial disparities in pain treatment noted, there are a multitude of factors that potentially lead to racial differences im treatment decisions:

Inadequate prescribing of analgesics for minority patients may result from many factors, including concern about potential drug abuse in minority patients, fewer resources with which to pay for analgesics, greater difficulty in accessing care and in filling analgesic prescriptions, and greater difficulty for the physician in assessing pain in minority patients because of differences in language and cultural background. Inadequate treatment may also result from the patient's fear of aggressive treatment, the patient's lack of assertiveness in seeking care, or a lack of expertise at the sites that treat patients belonging to ethnic minority groups. ${ }^{77}$

However, despite the progress in isolating various factors of racial disparities in medical treatment, studies have found that racial disparities persist even after a number of major possible explanatory variables-such as age, gender, clinical condition, severity of disease, and insurance

73. See e.g., David M. Carlisle, Racial and Ethnic Differences in the Use of Invasive Cardiac Procedures Among Cardiac Patients in Los Angeles County, I986 Through I988, 85 AM. J. PuB. HEALTH 352 (1995).

74. See Nancy De Lcw \& Robin M. Weinick, An Overview: Eliminating Racial, Ethnic, and SES Disparities in Health Care, 21 Health Care Fin. Rev. 1, 2 (2000).

75. See generally Knox H. Todd, Ethnicity as a Risk Factor for Inadequate Emergency Department Analgesia, 269 J. AM. Med. Ass'N 1537 (1993) (concluding that Hispanics with isolated long-bone fractures are twice as likely as non-Hispanic Whites to receive no pain medication in the University of California at Los Angeles emergency medicine center).

76. See, e.g., Scott A. Optenberg et al., Race, Treatment, and Long-Term Survival from Prostate Cancer in an Equal-Access Medical Care Delivery System, 274 J. Aм. Med. Ass'N 1599 (1995) (finding no racial disparities in treatment after controlling for financial access to treatment and accounting for differences in the stage of prostate cancer, in a study of patients in the U.S. Department of Defense medical system); see generally UNEQUAL TREATMENT, supra note 28, at 64-72.

77. Cleeland, supra note 70 , at 815. 
status-are taken into account. ${ }^{78}$ For instance, a 1993 study reported racial discrepancies between African American and White patients even after controlling for the type of heart disease and the patients' insurance status. ${ }^{79}$ The study found that White patients within the Veterans Administration ("VA") health system were more likely to undergo cardiac catheterizations and angioplasties than were African American patients within the same system. Moreover, Whites were more than twice as likely as African Americans to have bypass surgery, even after adjusting for differences in other complicating diseases, eligibility status within the VA system, the location of the hospital, and the availability of heart surgery services at each hospital. ${ }^{80}$

Studies have also demonstrated that disparities persist within similar socioeconomic groups and among individuals with the same level of insurance coverage. For instance, after controlling for differences in socioeconomic status, one study reported that African American children are twice as likely to have asthma and six times as likely to die from it as are White children.$^{81}$ Across income groups, racial disparities persist in the number of hospitalizations for asthma, which is generally considered a sign of inadequate treatment and management of the disease.$^{82}$ Similarly, im a study examining patients who were all Medicaid beneficiaries and thus had equivalent levels of coverage, African American children were more likely than White children to be treated for asthma in emergency departments and to be hospitalized for asthma, were less likely to have office visits for asthma treatment, ${ }^{83}$ and were less likely to receive the drug therapy recommended by the national asthma guidelines. ${ }^{84}$

In addition, studies on pain treatment have reported racial disparities in the treatment of pain where subjective pain scores reported by patients

78. See Llewellyn J. Comelius, Barriers to Medical Care for White, Black, and Hispanic American Children, 85 J. NAT'L MED. Ass'N 281, 284 (1993); Marian E. Gomick, Disparities in Medicare Services: Potential Causes, Plausible Explanations, and Recommendations, 21 Health CARE Fin. Rev. 23, 25 (2000); Jan E. Mutchler \& Jeffrey A. Burr, Racial Differences in Health and Health Care Service Utilization in Later Life: The Effect of Socioeconomic Status, 32 J. Health \& Soc. BEHAV. 342, 352 (1991).

79. Jeff Whittle et al., Racial Differences in the Use of Invasive Cardiovascular Procedures in the Department of Veterans Affairs Medical System, 329 NEw ENG. J. MED. 621 (1993); cf. Marian E. Gornick et al., Effects of Race and Income on Mortality and Use of Services Among Medicare Beneficiaries, 326 NEw ENG. J. MED. 791 (1996) (controlling for level of insurance); Eric D. Peterson et al., Racial Variation in the Use of Coronary-Revascularization Procedures, 336 NEW ENG. J. MED. 480 (1997).

80. Whittle, supra note 79, at 622-23.

81. KEY FACrs, supra note 38, at 30-31.

82. U.S. Dep't of Health \& Human Servs., Health Res. and Servs. Admin., Health Care RX: ACCESS FOR ALL (1998).

83. Paula Lozano et al., Use of Health Services by African American Children with Asthma on Medicaid, 274 J. AM. MED. Ass'N 469 (1995).

84. Id. 
of different minority groups did not differ statistically from one another ${ }^{85}$ and where researchers controlled for variables such as age, sex, site of the surgery, and history of preoperative narcotic use. ${ }^{86}$

\section{Summary}

There is a tremendous amount of evidence that African Americans do not fare as well as Whites in the American health care system. Studies have consistently documented a substantial gap between the health status of African Americans and Whites according to a variety of indicators and in a wide array of medical areas. Moreover, there is growing evidence that a large part of the disparity in health status can be attributed to differences in the medical treatment provided to African American and White patients. And while researchers have successfully identified a number of different socioeconomic and demographic variables that appear to contribute to racial disparities in medical treatment, subsequent studies have found that racial disparities in medical treatment persist even after controlling for these variables. This leaves open the possibility that racial disparities in treatment are caused, at least in part, by psychological factors on the part of health care providers. The next Part further examines this possibility.

II

\section{The Psychology of Medical Decision Making}

In trying to account for the reported racial disparities in medical treatment, recent studies have considered internal psychological factors such as patient and doctor attitudes. For example, racial disparities unight result in part from differences in patient preferences: minority patients might receive certain medical treatments less frequently because they choose not to accept the treatment. ${ }^{87}$ Indeed, there is at least some evidence that suggests that African American patients generally are more averse to surgery than are White patients. ${ }^{88}$

The mindset of patients, however, is only part of the equation. The attitudes of health care providers may play a crucial role in producing disparate treatment decisions. As one researcher suggests:

The doctor apparently arrives at the patient's bedside with preconceived notions about the patient's needs for pain medication,

85. Bernardo $\mathrm{Ng}$ et al., The Effect of Ethnicity on Prescriptions for Patient-Controlled Analgesia for Post-Operative Pain, 66 PaIN 9 (1996).

86. Bernardo Ng et al., Ethmic Differences in Analgesic Consumption for Postoperative Pain, 58 Psychosomatic Med. 125 (1996).

87. Watson, supra note 10, at 209. As discussed later in this Part, these patient preferences regarding treatment might not simply be baseline differences but might in fact reflect patients' distrust of the caregivers caused by the caregivers' implicit cognitive bias. See discussion infra Part II.B.2.

88. Eugene Z. Oddone et al., Understanding Racial Variation in the Use of Carotid Endarterectomy: The Role of Aversion to Surgery, 90 J. NAT'L MED. Ass'N 25 (1998). 
notions that are tied to ethnicity and not to the illness per se. What is worse is that there are no data to suggest that such perceptions are accurate, nor are physicians even aware of their behavior. ${ }^{89}$

In recent years, researchers have increasingly focused their attention on individual-centered psychological variables in addressing the question of whether and to what extent the attitudes and beliefs of caregivers influence medical decision making. This Part begins by reviewing several recent studies that indicate that a patient's race, apart from any other external variables, can differentially affect a medical caregiver's treatment decisions for White and African American patients. It then explores how implicit cognitive bias might contribute to this differential treatment, focusing speciflcally on how implicit attitudes and stereotypes might influence caregiver decisions in a clinical setting.

\section{A. Psychological Variables that May Contribute to Racial Disparities in Medical Treatment}

Recently, studies have begun to examine the possibility that racial disparities in medical treatment stem in part from differences, based solely on the race of patients, in physicians' recommendations..$^{90}$ In 1999 , a study by Kevin Schulman and others reported significant differences in physicians' responses to identical heart disease symptoms presented by African American and White actors portraying patients. ${ }^{91}$ Seven-hundred-andtwenty primary care physicians were shown scripted, videotaped interviews of hypothetical patients, given additional clinical information about their "patients," and asked to make follow-up clinical recommendations. ${ }^{92}$ The actors were dressed in an identical manner, had identical insurance and occupations, and presented their clinical symptoms according to a fixed script. ${ }^{93}$

The researchers used multivariate-logistic-regression analysis to assess the effects of race and sex of the patients on treatment recommendations, while controlling for the age of the patient, the level of coronary risk, the type of chest pain, and the results of an exercise stress test. ${ }^{94}$ The results showed that the physicians referred lower proportions of African American than White patients (matched for age and sex) for cardiac catheterization, a costly state-of-the-art diagnostic technique. This was true even after the

89. Joel E. Dimsdale, Stalked by the Past: The Influence of Ethnicity on Health, 62 Psychosomatic Med. 161, 164 (2000).

90. See generally UNEQUAL TREATMENT, supra note 28, at 27-41.

91. Kevin A. Schulman et al., The Effect of Race and Sex on Physicians' Recommendations for Cardiac Catherization, 340 New ENG. J. MED. 618 (1999).

92. Id.

93. Id. at 624 .

94. Id. at 623 . 
researchers controlled for the physicians' subjective impression of disease likelihood and severity. ${ }^{95}$

The researchers controlled for differences in the physicians' perceptions of the prevalence of disease according to the race of the patients by incorporating the physicians' assessment of the probability of coronary artery disease into the analysis. ${ }^{96}$ By collecting detailed information about the physicians' perceptions of the patients' personalities and other attributes, the researchers also assessed the possibility that the physicians' recommendations for the procedure simply reflected their perceptions of the patients' personalities rather than the race of the patients. But including this information in the analysis did not affect the results. ${ }^{97}$ They concluded that the results "suggest that a patient's race and sex may influence a physician's recommendation with respect to cardiac catheterization regardless of the patient's clinical characteristics" and that this "may suggest bias on the part of the physicians." 98

In a more recent study, Carol Weisse and others used an experimental design similar to the Shulman-study design and also found that varying patients' race led to differential outcomes. ${ }^{99}$ In the Weisse study, researchers showed patient vignettes to physicians and recorded the recommendations for prescriptions of pain medicine. ${ }^{100}$ Physicians prescribed higher doses of pain medication for White patients than they did for African American patients despite the fact that the patients displayed identical symptoms of pain in the vignettes. ${ }^{101}$

A study by Saif Rathore and others suggests that at least part of what accounts for the race-based differential treatment recommendations reported in the Shulman and Weisse studies is that the information about the race of a patient influences physicians' perceptions of the severity of the patient's symptoms and thereby affects physicians' diagnoses of the patients' conditions. ${ }^{102}$ Researchers in the Rathore study showed medical students a video of either an African American female patient or a White male patient presenting identical symptoms of angina. ${ }^{103}$ They reported that the

95. Id. The editors of the New England Journal of Medicine later responded to criticisms of the paper's statistical presentation of the study's findings by stating that "the evidence of racism and sexism in this study was overstated." Gregory D. Curfman \& Jerome P. Kassirer, Race, Sex and Physicians' Referrals for Cardiac Catheterization (The Editors Reply), 341 NEw ENG. J. MED. 287 (1999).

96. Schulman, supra note 91 , at 624 .

97. Id.

98. Id. at 624 .

99. Carol S. Weisse et al., Do Gender and Race Affect Decisions About Pain Management?, 16 J. GEN. INTERNAL MED. 211 (2001).

100. Id. at 211-12.

101. Id. at 215-16.

102. Saif R. Rathore et al., The Effects of Patient Sex and Race on Medical Student Ratings of Quality of Life, 108 AM. J. MED. 561 (2000).

103. Id. at 562. 
students who viewed the video of the White male patient provided a diagnosis of "definite angina" more often than students who saw the video of the African American female patient. ${ }^{104}$ Additionally, the students perceived the same symptoms as more severe for the White male patient than for the African American female patient. ${ }^{105}$

The conclusions to be drawn from these studies are limited because they shed little light on the root causes of the reported effects. Moreover, it appears that the race of the patient is only one of a number of interacting variables that influence treatment choice. For instance, the results of the Shulman study revealed significant sex differences, with men more likely to be referred for the procedure than women, suggesting that the effects of the race of the patient interact with the effects of the gender of the patient. ${ }^{106}$ Likewise, the Weisse and Rathore studies indicate that both the gender and race of the physician are variables of significance. In the Rathore study, the researchers found that while White students rated the symptoms of the White male patient as more severe than those of the African American female patient, minority students rated the symptoms as equally severe. ${ }^{107}$ And in the Weisse study, the researchers found that while male physicians prescribed higher doses of pain medication for White patients than for African American patients, the reverse was true for female physicians. $^{108}$

Whether or not they provide a complete picture, these studies serve as an indication that a patient's race-isolated from any connections to other explanatory variables such as insurance level, socioeconomic status, or the severity of the condition presented-influences physicians' treatment decisions. The studies suggest that two patients, indistinguishable in every conceivable manner and presenting objectively identical symptoms but differing in race, would fare differently in the American health care system. Thus, the findings in the studies seem inevitably to lead to the conclusion that one significant cause of racial disparities in medical care is racial bias on the part of the medical caregiver. And as Shulman and his coauthors observed, this bias likely resides beneath the surface: "Bias may represent overt prejudice on the part of physicians or, more likely, could be the result of subconscious perceptions rather than deliberate actions or thoughts."109

104. Id. at 563-64. While these findings are consistent with the results of the Shulman and Weisse studies, their generalizability is limited by the fact that the researchers did not utilize all four cells of the experimental design by including a White female patient and an African American male patient. Id. at 565 .

105. Id. at 563-64.

106. Shulman, supra note 91 , at 621-23.

107. Rathore, supra note 102, at 563-64.

108. Weisse, supra note 99 , at 215-16.

109. Shulman, supra note 91 , at 624-25. 
The next Section further explores the idea that racial disparities in health care result in part from implicit cognitive bias on the part of medical caregivers. It summarizes some recent psychological findings on implicit attitudes and beliefs and examines potential mechanisms by which implicit cognitive bias may work to produce racially disparate outcomes in a clinical setting.

\section{B. Cognitive Bias in Medical Decision Making}

\section{The Nature of Modern Bias}

Psychological survey studies of racial and ethnic attitudes and beliefs have tracked a marked decrease in overt prejudice since the start of the civil rights movement. These studies show that while a majority of White Americans expressed overt racial prejudice in the 1950 s, few do today. ${ }^{110}$ To the contrary, the survey evidence indicates that for the most part White Americans expressly endorse racial equality in schools, housing, jobs, and politics. ${ }^{111}$ However, despite the apparent decline of overt racial prejudice, contemporary psychological theorists have stopped far short of concluding that prejudice is a thing of the past. Rather, most contemporary models of prejudice interpret the evidence that express racial prejudice has largely disappeared merely as an indication that racial prejudice has changed in form. One group of researchers observes:

A cornerstone of many recent models of prejudice is the assumption that, in response to normative expectations, there have been fundamental changes in the nature of people's attitudes. Specifically, people's attitudes have shifted from predominantly reflecting negativity to being more mixed or ambivalent in nature. A theme common in contemporary theories of prejudice is that Whites experience a conflict between two competing tendencies in their reaction towards Blacks. One tendency encourages positive or nonprejudiced responses; the other encourages negative or prejudiced responses. In some cases, theorists argue that, in response to normative prescriptions against overt bias, prejudice has gone underground or that it has been transformed into subtle and increasingly covert expressions of prejudice. ${ }^{112}$

Most contemporary prejudice models therefore distinguish explicit, overt forms of prejudice from subtle, implicit forms. Moreover, according to these modern models, the implicit form of prejudice need not be

110. Patricia G. Devine et al., Classic and Contemporary Analyses of Racial Prejudice, in Blackwell Handbook of Social Psychology: Intergroup Processes 200 (Rupert J. Brown \& Samuel L. Gaertner eds., 2001).

111. See John F. Dovidio \& Samuel L. Gaertner, Prejudice, Discrimination, and Racism: Historical Trends and Contemporary Approaches, in PREJUDICE, DISCRIMINATION AND RACISM 1-34 (John F. Dovidio \& Samuel L. Gaertner eds., 1986).

112. Devine, supra note 110, at 201. 
accompanied within individuals by the explicit type. ${ }^{113}$ Thus, while recent survey studies measuring racial prejudice indicate that the prevalence of explicit racial prejudice in White Americans appears to have decreased dramatically in recent decades, these studies do not speak to the issue of the prevalence of implicit racial prejudice. ${ }^{114}$ Indeed, there is substantial empirical evidence indicating that implicit prejudice remains widespread even in individuals who, on an explicit level, are genuinely unprejudiced. ${ }^{115}$ Recent findings locate implicit prejudice principally within two inain cognitive domains: attitudes and stereotypes. ${ }^{116}$

\section{a. Implicit Attitudes}

Psychology researchers typically define attitudes as positive or negative dispositions toward objects in one's social environment. ${ }^{117}$ While researchers traditionally have focused on attitudes that are consciously accessible (using, for example, self-report testing measures), in recent years mounting empirical evidence indicates that attitudes can be implicit as well as explicit. ${ }^{118}$ Implicit attitudes can be thought of as "introspectively unidentified (or inaccurately identified) traces of past experience that mediate favorable or unfavorable feeling, thought, or action toward social objects." 119 Thus, by definition, implicit attitudes operate outside of conscious awareness. Moreover, they are automatically activated by the inere presence of the attitude object. ${ }^{120}$

While explicit attitudes towards a social object sometimes correspond with implicit attitudes toward that object, they often do not. ${ }^{121}$ Because implicit attitudes are governed by automatic, uncontrolled processes, they cannot be as easily manipulated as explicit attitudes. ${ }^{122}$ Thus, while one can alter his or her explicit attitudes to conform to prevailing social norms,

113. See Devine, supra note 110, at 202 (describing several modern theories of prejudice); John F. Dovidio, On the Nature of Contemporary Prejudice: The Third Wave, 57 J. Soc. 1ssues 829, 831-33 (2001) (same).

114. Id. at $838-39$

115. Id.

116. Devine, supra note 110 , at 200-04.

117. Anthony G. Greenwald \& Mahzarin R. Banaji, Implicit Social Cognition: Attitudes, SelfEsteem, and Stereotypes, 102 PsYchoL. REV. 4, 7 (1995); see also Alice H. Eagly \& Shelly Chaiken, Attitude Structure and Function, in 1 THE HANDBOOK OF SOClaL PSYchology 269 (Daniel T. Gilbert et al. eds., 1998) (defining an attitude as "a psychological tendency that is expressed by evaluating a particular entity with some degree of favor or disfavor").

118. See Greenwald \& Banaji, supra note 117, at 7-10.

119. Id. at 8 .

120. John F. Dovidio et al., Implicit and Explicit Attitudes: Examination of the Relationship Between Measures of Intergroup Bias, in BLACKWELL HANDBOOK OF SOCIAL PSYCHOLOGY: INTERGRouP PROCESSES 176-77 (Rupert J. Brown \& Samuel L. Gaertner eds., 2001).

121. Id.

122. Id. 
changing corresponding implicit attitudes is more difficult. ${ }^{123}$ As one researcher has described it:

With experience or socialization, people change their attitudes. The original attitude is not replaced, however, but rather is stored in memory and becomes implicit, whereas the newer attitude is conscious and explicit. In general, explicit attitudes can change and evolve relatively easily, whereas implicit attitudes, because they are rooted in overlearning and habitual reactions, persist and are much more difficult to alter. ... One factor that may determine the evaluative correspondence of the implicit and explicit evaluations involved in dual attitudes is the normative context for the attitude object. For instance, people may initially acquire negative attitudes towards groups through socialization within a particular cultural or historical context. Later, when norms change or the person is exposed to new normative proscriptions that dictate people should not have these negative feelings toward these groups, people adopt explicit unbiased or positive attitudes. Nevertheless, negative implicit attitudes linger. ${ }^{124}$

Thus, many current theoretical models predict that implicit and explicit attitudes are especially likely to diverge when they involve socially sensitive issues, such as issues of race, because the normative social context forces individuals to alter their explicit beliefs more quickly than they can adjust corresponding implicit attitudes. ${ }^{125}$ This suggests that implicit prejudicial racial attitudes linger even in individuals who are explicitly unprejudiced. Recent empirical work has firmly supported this prediction. ${ }^{26}$

Some of the most consistent and robust evidence for the existence and operation of implicit attitudes comes from studies that utilize the Implicit Association Test ("IAT"). The IAT uses a five-step procedure to measure implicit attitudinal responses by gauging differential associations between evaluative categories. ${ }^{127}$ It uses two separate sets of words: (1) a "target" set of words that includes words from two categories (for example, "weapons" and "musical instruments") and (2) a set of evaluative words, some pleasant and others unpleasant. Participants are initially presented with the task of sorting the target words on the basis of category membership-the target set of words are flashed on a computer screen and participants sort the words into the categories "weapons" and "musical instruments" by striking a keyboard key (for example, the left shift key) to

123. Id.

124. Dovidio, supra note 113 , at 839.

125. Id.; see also Dovidio et al., supra note 120 , at 177.

126. See generally id. at 178-79; Dovidio, supra note 113, at 837-38; Greenwald \& Banaji, supra note 117 , at 7-8.

127. See Dovidio et al, supra note 120, at 180. See Implicit Assocation Test, Home PaGe, at http://buster.cs.yale.edu/implicit/index.html, for more information about the IAT and a version of the test itself. 
indicate "weapons" and another (for example, the right shift key) to indicate "musical mstruments." 128 In the second step, the participants use the same procedure to sort the set of evaluative words. Thus, for example they press one key (for example, the left shift key) for "pleasant" words and the other (for example, the right shift key) for "unpleasant" words. ${ }^{129}$ In the third step, the first two steps are combined: words from both the target set and the evaluative set are interspersed and presented, and using the saine sorting keys from the first two steps (for example, left shift for weapons and pleasant words; the right shift key for musical instruments and unpleasant words), the participants sort the words into their respective categories. ${ }^{130}$ In the fourth step, the words from the evaluative set are presented again, but this time, the keys used to denote the evaluative categories are reversed (the left shift key for unpleasant words; the right shift key for pleasant words), and the participants go through a trial categorizing the evaluative word-set using the new key designations. ${ }^{131}$ Finally, in the fifth step, the words from both the target set and the evaluative set are again intermingled and the participants categorize the words just as they did in the third step, except that they use the new key designations for the evaluative categories (the left shift key for weapons and unpleasant words; the right shift key for musical instruments and pleasant words). ${ }^{132}$

The IAT measures implicit attitudes by comparing the response times in steps three and five. ${ }^{133}$ If the participant has a more positive attitude toward one of the target categories (for example, musical instruments) than toward the other (for example, weapons), the categories will be differentially associated with the pleasant-unpleasant category. ${ }^{134}$ In other words, there will be a closer connection between the category that the participant likes better and the pleasant words. As a result, the participant's response times in steps three and five should reflect this discrepancy. ${ }^{135}$ For instance, the developers of the IAT showed that participants consistently responded more quickly when one key was used to denote weapons and unpleasant words and the other key was used to designate musical instruments and pleasant words than when they sorted using the reverse key combination

128. Anthony G. Greenwald et al., Measuring Individual Differences in Implicit Cognition: The Implicit Association Test, 74 J. Personality AND Soc. Psychol. 1464, 1465-67 (1998). Examples of positive words include health, love, peace, and cheer, while examples of negative words include abuse, crash, murder, stink, and hatred. Id. at 1479.

129. Id. at 1465-67.

130. Id.

131. Id.

132. Id.

133. Id.

134. Id. at 1465-66.

135. Id. 
(weaponspleasant and musical instrumentsunpleasant). ${ }^{136}$ Thus, as predicted, the IAT demonstrated that the participants' implicit attitudes toward musical instruments were more positive than their implicit attitudes toward weapons. ${ }^{137}$

A number of recent studies have used the IAT to identify implicit racial attitudes by measuring associations between race-related stimuli and evaluative words. ${ }^{138}$ For instance, several studies have shown that direct measures of individuals' levels of prejudice do not predict their implicit attitudes as measured by the strength of their evaluative associations to typically African American and typically White names. In these studies, participants responded significantly more slowly when African American names were paired with pleasant words and White names were paired with unpleasant names than when the reverse was true. ${ }^{139}$ Similarly, studies using pictures of faces have demonstrated that individuals who show no signs of prejudice on explicit measures of attitudes have more negative implicit attitudes toward pictures of African American faces than toward pictures of White American faces. ${ }^{140}$

In a broad-based study using over six-hundred-thousand applications of the IAT across several years, one set of researchers reported that while there is some variance between individuals and between different social groups, negative implicit attitudes towards African Americans seem to be pervasive within the American population. ${ }^{141}$ The researchers who conducted the study stated, "From young to old, male to female, African American to White, and conservative to liberal, implicit biases are not held by a select few but are readily observed among all social groups."142

136. Id. at 1467-69. The researchers alternated the key combinations and category order across participants to ensure the effect did not depend on procedural variables. $I d$.

137. Id. at $1469-70$.

138. Id. at 1473-76; Nilanjana Dasgupta et al., Automatic Preference for White Americans: Eliminating the Familiarity Explanation, 36 J. EXPERIMENTAL PSYCHOL. 316 (2000); Scott A. Ottaway et al., Implicit Attitudes and Racism: Effects of Word Familiarity and Frequency in the Implicit Association Test, 19 Soc. CogNITION 97 (2001).

139. See Greenwald et al., supra note 128, at 1473-76. Typical African American names included, for example, Alonzo, Theo, Darnell, Aiesha, Tameka, and Lashelle, while typical White American names included Adam, Chip, Stephen, Courtney, Nancy, and Rachel. Id.at 1479. An alternative explanation for these effects might be that the response times reflect less familiarity with African American names rather than any negative evaluation of them. See id. at 1477. However, subsequent studies have tested and rejected this familiarity explanation. See Dasgupta et al., supra note 138; Ottaway et al., supra note 138.

140. Brian A. Nosek et al., Harvesting Implicit Group Attitudes and Beliefs from a Demonstration Web Site, 6 Group DYNamics 101 (2002).

141. Id.

142. Id at 112 . 


\section{b. Implicit Stereotypes}

While related to implicit attitudes, implicit stereotypes comprise a theoretically distinct subset of implicit bias. ${ }^{143}$ As noted above, attitudes are evaluative responses to social objects; stereotypes, in contrast, are beliefs about particular groups. ${ }^{144}$ Thus, implicit stereotypes can be defined as "the introspectively unidentified (or inaccurately identified) traces of past experience that mediate attributions of qualities of a social category." 145 In other words, implicit stereotypes are subconscious mental representations of social categories - representations which involve knowledge, beliefs, and expectations about social groups. ${ }^{146}$

Just as there is evidence of a split between explicit and implicit attitudes, there is growing evidence of a split between implicit stereotypes and explicit prejudicial beliefs about groups. ${ }^{147}$ According to Professor Patricia Devine's "Dissociation Model," implicit stereotypes represent knowledge about attributes stereotypically associated with a particular group while explicit prejudiced beliefs involve the conscious endorsement or acceptance of the negative stereotype. ${ }^{148}$ The presence of implicit stereotypes within an individual does not necessarily entail open endorsement of the stereotype. ${ }^{149}$ Under Devine's model, the repeated exposure to and activation of cultural stereotypes, which are inevitably part of one's socialization, eventually lead to the automatic activation of stereotypes as a "default basis" for responding to members of the stereotyped group..$^{150}$ Therefore, according to Devine's model, given the prevalence of racial stereotypes in American society today, most Americans have learned and internalized a variety of negative racial stereotypes over time. ${ }^{151}$ The result is that even those who explicitly renounce negative racial stereotypes are susceptible to the automatic activation and unintentional application of those same stereotypes.

As evidence of the use of implicit stereotypes, researchers have found a stronger association between positive traits and whiteness among White subjects. ${ }^{152}$ For example, when subjects are presented with pairs of letter strings and given the task of determiming whether both strings comprise words, White subjects respond reliably faster when the word "white" was paired with positive trait words than when the word "black" was paired

143. Dovidio et al., supra note 120 , at 186.

144. Id.

145. Greenwald \& Banaji, supra note 117 , at 15 .

146. See Ziva Kunda, Soclal Cognition: Making Sense of People 314-15 (1999).

147. Devine, supra note 110, at 203-04.

148. Id.

149. Id.

150. Id.

151. Id.

152. Samuel L. Gaertner \& John P. McLaughlin, Racial Stereotypes: Associations and Ascriptions of Positive and Negative Characteristics, 46 Soc. PsYCHOL. Q. 23 (1983). 
with positive trait words-for example, "white" and "smart" contrasted with "black" and "smart." This association emerged regardless of how the subjects scored on direct, self-report measures of race prejudice. ${ }^{153}$ In a similar study, researchers presented either the word "black" or the word "white" followed by a trait word and asked the subjects to judge whether the trait could "ever be true" or was "always false" of the preceding category. ${ }^{154}$ They found that subjects responded faster when positive traits followed "white" and negative traits followed "black" than when the reverse combinations were presented. 155

Research also supports the idea that implicit stereotypes are automatically activated. ${ }^{156}$ One trait that people frequently mention in survey studies as being associated with the stereotype for African Americans is hostility. Researchers have found that presenting White subjects words stereotypically associated with African Americans (for example, poor, jazz, slavery, Harlem) or subliminally exposing subjects to pictures of African American faces automatically activates the construct of hostility. For example, subjects interpret ambiguous actions described in hypothetical scenarios as being more hostile when they are exposed to the African American stereotype words than when they are not. ${ }^{157}$ Another study has shown that subliminal presentation of the word "black" can activate in White subjects negative aspects of the African American stereotype, including thoughts of poverty, laziness, and violence. ${ }^{158}$

\section{c. Summary}

In sum, there is substantial empirical support for the existence of implicit cognitive bias against African Americans in the form of both negative implicit attitudes and negative implicit stereotypes. This implicit cognitive bias is governed by uncontrolled and unintentional processes, runs below the level of conscious awareness, and can be activated automatically by neutral reminders of African Americans. Moreover, the bias is not tied to explicit attitudes and beliefs, and thus, it can be present in

153. Id.

154. Samuel L. Gaertner \& John F. Dovidio, The Aversive Form of Racism, in PREJUdice, Discrimination, AND RaCism 61-89 (John F. Dovidio \& Samuel L. Gaertner eds., 1986).

155. Id. While similar, these studies are conceptually distinct from the studies mentioned earlier that measure implicit attitudes. Whereas the latter gauge basic evaluative responses by measuring the connection between a racial category and evaluative words, such as pleasant and unpleasant words, the former examine nonevaluative belief struetures by measuring the association between a racial category and trait words. The fact that an individual assoeiates a negativc trait with a particular category does not necessarily mean that the individual harbors a negative attitude towards members of that category. For example, one might like cats despite thinking that they are fussy or aloof.

156. KUNDA, supra note 146, at 318-21.

157. Id.

158. Id. at 322 . 
individuals who on the surface appear to be, and perhaps genuinely believe themselves to be, unprejudiced.

\section{The Effects of Cognitive Bias in the Clinical Setting}

This section applies recent psychological findings regarding the behavioral effects of implicit cognitive bias, in the form of implicit attitudes and implicit stereotypes, to the clinical setting. Specifically, it examines how implicit attitudes might weaken the relationship between the patient and the medical caregiver, as well as how implicit racial stereotypes might color the judgment of medical caregivers in a way that ultimately could lead to disparate outcomes im medical treatment.

\section{a. The Potential Effects of Implicit Attitudes on the Patient-Caregiver Relationship}

Given that implicit attitudes are governed by automatic, unintentional processes, most theoretical models of attitudes predict that implicit attitudes manifest themselves in spontaneous, nonverbal behaviors, as opposed to deliberative, controlled behaviors, which are linked to explicit attitudes. ${ }^{159}$ Several recent studies support these predictions. ${ }^{160}$ One study, for example, found that while implicit attitudes were correlated with spontaneous, nonverbal measures of friendliness, but not with ratings of verbal friendliness, the reverse was true of explicit attitudes. ${ }^{161}$ In the study, White subjects engaged in face-to-face interactions with African American subjects, and researchers measured the African American subjects' ratings of verbal friendliness, as well as two objective, nonverbal imdicators of friendliness: visual contact (which has been found to reflect greater attention, intimacy, and respect) and rates of blinking (which imdicate the level of negative arousal and tension). The researchers found that the explicit attitudes of the White subjects were correlated to the African American subjects' ratings of verbal friendliness, but that the implicit attitudes of the White subjects were not. In contrast, the researchers reported that negative implicit attitudes of the White subjects were linked with lower levels of visual contact and higher rates of blinking, but they found no relationship between the White subjects' explicit attitudes and the two nonverbal friendliness measures. ${ }^{162}$

159. See Dovidio, supra note 113, at 840-41; Russell H. Fazio, Multiple Processes by Which Attitudes Guide Behavior: The MODE Model as an Integrative Framework, in ADVANCES IN Experimental Social Psychology 75 (Mark P. Zanna ed. 1990); see generally Dovidio et al., supra note 120 , at 177 .

160. See Dovidio, supra note 113 , at $840-41$; Russell H. Fazio et al., Variability in Automatic Activation as an Unobtrusive Measure of Racial Attitudes: A Bona Fide Pipeline?, 69 J. Personality \& Soc. Psychol. 1013 (1995).

161. See Dovidio, supra note 113, at 841.

162. Id. 
Further research has demonstrated that while Whites are unaware of spontaneous unfriendly behaviors caused by negative implicit attitudes, African Americans are especially attuned to those behaviors during social interactions. ${ }^{163}$ Thus, researchers have found that White and African American participants form very different impressions of interactions when implicit attitudes are at work. In one study, White participants' ratings of the friendliness of their behavior were closely tied to the outward friendliness of their own verbal behavior and were uncorrelated with nonverbal indicators of friendliness (blinking and eye contact). ${ }^{164}$ For African American participants, however, the reverse was true; African American participants' ratings of the friendliness of White participants' behavior were tied to the nonverbal indicators, and not the verbal indicators, of friendliness. ${ }^{165}$

These findings have potentially far-reaching implications in the context of medical treatment. As noted above, implicit attitudes can be activated automatically, and in some cases instantly, by the mere presence of a social object. If negative implicit racial attitudes, which arise automatically in the presence of African American patients, give rise to spontaneous, unintentional unfriendly behavior to which the patients are especially attuned, the implicit attitudes could weaken the patient-caregiver relationship, lowering the quality and effectiveness of medical care. For instance, if an African American patient is able to perceive negative, implicit racial attitudes on the part of the caregiver, the patient may be less trusting of the caregiver and as a consequence may be more likely to refuse invasive procedures or may be less likely to comply with treatment recommendations. ${ }^{166}$ Indeed, there is at least some evidence that patient refusal of treatment contributes to racial disparities in medical care. ${ }^{167}$ Moreover, patient mistrust and refusal to comply with treatment recommendations may lead providers to become less engaged in the treatinent process and less willing, for example, to suggest alternative treatments and services, starting a vicious cycle that deteriorates the patient-caregiver relationship. ${ }^{168}$

\section{b. The Potential Effects of Implicit Stereotypes on Medical Decision Making}

Implicit stereotyping is a basic process of social categorization that has little to do with one's conscious attitudes. Rather, implicit stereotypes are largely a product of one's surroundings; exposure to and knowledge of racial stereotypes cause individuals to internalize those stereotypes as

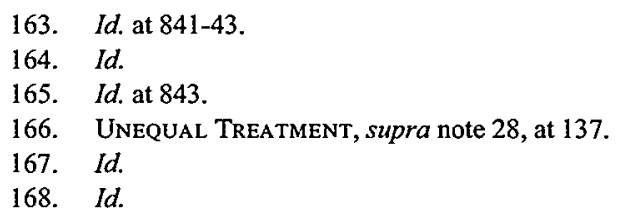


implicit, automatically activated beliefs. As a result, the fact that medical caregivers generally are highly educated individuals who are likely to endorse egalitarian ideals has little bearing on whether they are likely to engage in implicit stereotyping. ${ }^{169}$ The question instead is whether implicit racial and ethnic stereotypes about patients are pervasive within the medical community. There is growing evidence that the answer to this question is yes. ${ }^{170}$

In a focus-group discussion survey, for example, hospital administrators listed examples of racial and ethnic stereotypes, including: "Asians won't discuss symptoms or complain;" "[o]btaining medical history information from immigrants is impossible;" "Native Americans don't show emotion;" "Asians won't complete prescription drug regimens;" and "Hispamics and African Americans won't lose weight or eat healthy diets." $"$ In another study, researchers found that some physicians tend to believe that African American patients are less likely to coinply with treatment and more likely to engage im unhealthy behaviors (such as drug use) that interfere with medical treatment. ${ }^{172}$

Because implicit stereotypes operate below the level of consciousness, their effects on conscious activity are difficult to discern and usually go unnoticed. ${ }^{173}$ However, implicit stereotypes can impact conscious judgment-making processes. ${ }^{174}$ As discussed earlier, any cues reminding one of a social group, even subliminal cues, will activate implicit stereotypes about that group. ${ }^{175}$ For example, just looking at an African American person may spontaneously bring to mind stereotypical traits such as "aggressive" or "criminal." The activation of these stereotypic traits can greatly influence how one subsequently perceives and interprets the behavior of an African American person, as well as how one will predict that person's future behavior. ${ }^{176}$

Because the automatic activation of an implicit stereotype involves heightened accessibility of stereotype-related traits, the perceiver unknowingly forms an expectation regarding the behavior of a member of the

169. Monica Beirnat \& John F. Dovidio, Stigma and Stereotypes, in THE Social Psychology of STIGMA 88 (Todd F. Heatherton ed., 2000).

170. See, e.g., Dimsdale, supra note 89; Michelle van Ryn \& Jane Burke, The Effect of Patient Race and Socioeconomic Status on Physician's Perceptions of Patients, 50 Soc. ScI. \& MED. 813, 813 (2000); Frederick Schneiders Research, Perceptions of How Race \& Ethnic Background Affect Medical CARe: Highlights From Focus Groups (Oct. 1999), available at http://www.kff.org/content/1999/19991014a/FOCUS\%20GROUP.pdf [hereinafter PERCEPTIONS].

171. Id.

172. van Ryn \& Burke, supra note 170.

173. See KUNDA, supra note 146, at 346-51.

174. Id.

175. See discussion supra Part II.B.I.b.

176. Mark Chen \& John A. Bargh, Nonconsious Behavioral Confirmation Processes: The SelfFulfilling Consequences of Automatic Stereotype Activation, 33 J. EXPERIMENTAL Soc. PsYchol. 541, 546 (1997); KuNDA, supra note 146, at 346-51. 
stereotyped group. ${ }^{177}$ This expectation in turn causes the perceiver to selectively attend to aspects of the behavior and surrounding environment that correspond with his or her expectations. ${ }^{178}$ Moreover, these expectations not only influence the perception of behavior, but in some mstances can alter the underlying behavior itself. Expectations may lead the perceiver to engage unintentionally and unknowingly in spontaneous stereotypeconfirming behavior that causes the other person to respond in kind, thus creating a "self-fulfilling prophecy." 179

Implicit stereotypes are especially likely to influence the perception and interpretation of behavior in two types of situations that commonly occur in a clinical setting. The first is where the mental capacity of the perceiver is constrained. ${ }^{180}$ There is evidence that individuals are more prone to rely on implicit stereotypes when their cognitive resources are limited or strained, such as when they are tired, distracted, or pressed for time. ${ }^{181}$ This effect may be explained by the possibility that, because implicit stereotyping is an automatic, unintentional process, it is simply cognitively easier to rely on implicit stereotypes than to use actual individuating information. ${ }^{182}$ Under this view, stereotypes serve as effortless, easy-to-use heuristics that simplify the judgment-making process. ${ }^{183}$ Given the high-pressure, busy nature of medical caregiver professions, those who provide care in clinical settings may be especially inclined to rely on these mental shortcuts.

The second type of situation in which implicit stereotyping is particularly likely to occur is when the underlying behavior to be interpreted is somewhat ambiguous. ${ }^{184}$ When behavior is ambiguous it is open to multiple interpretations, and thus it is particularly easy for a perceiver to selectively attend to and interpret aspects of the target's behavior in ways that confirm the expectations created by implicit stereotypes. In the context of medical care, patients' behavior is inherently aubignous. Most medical decisions do not rest entirely on firm empirical evidence but rather depend in part on the discretion of clinical caregivers. For most medical situations, physicians generally have multiple diaguostic and therapeutic options, and there are wide variations in the use of medical and surgical procedures

177. See John M. Darley \& Russell H. Fazio, Expectancy Confirmation Processes Arising in the Social Interaction Sequence, 35 AM. Psychologist 869 (1980).

178. Id; see generally KUNDA, supra note 146, at 358-61.

179. See Chen \& Bargh, supra note 176 , at $547-48$.

180. See KUNDA, supra note 146 , at $358-61$.

181. Id.

182. Id. at 360 .

183. An alternate explanation for the results is that inhibiting the use of implicit stereotypes or filtering their effects requires effort, and thus, when one is cognitively busy, he or she does not have the cognitive resources to prevent implicit stereotypes from influencing his or her judgments. Id.

184. Id. at 353-58. 
among individual practitioners, even within small geographic areas. ${ }^{185}$ Moreover, for many medical decisions, there is not sufficient scientific evidence to support a consensus about appropriate diagnostic and therapeutic measures, and even when possible outcomes are empirically predictable, lack of agreement on how to evaluate clinical outcomes amplifies variations in medical practice. ${ }^{186}$

The pervasiveness of clinical discretion in all stages of medical care thus opens up the possibility that physicians' implicit stereotypes will affect the treatment decisions that they make in the course of providing medical care. ${ }^{187}$ For instance, a doctor's negative presumptions about a patient's truthfulness, self-discipline, laziness, level of suffering, tolerance for pain, or intelligence inight reduce the doctor's willingness to believe the patient's self-reported symptoms and thereby alter the doctor's diagnoses or treatment recommendations. ${ }^{188}$ Indeed, some evidence suggests that racial disparities in the treatment of pain are caused in part by doctors being less willing to believe an African American patient's self-report of pain than they are to believe a White patient's self-report of pain. ${ }^{189}$ Physicians' expectations regarding the likelihood that a patient will comply with treatment recommendations might also influence treatment decisions. For example, assuinptions about a patient's willingness or ability to follow recommendations, as well as suppositions about the presence of factors such as substance abuse, poor living conditions, or lack of social support, might alter physicians' decisions to pursue risky or costly courses of treatment. ${ }^{190}$ Presuinptions stemming from physicians' implicit stereotypes might also create a self-fulfilling prophecy by causing the doctors to act in a way that leads the patient to behave in conformity with their presumptions. For example, if the doctor does not expect the patient to comply with treatment recommendations, he or she might not give the recommendation as assertively as he or she otherwise might, which in turn might make the patient less likely to comply. Or if perceived by the patient, these negative suspicions and expectations may lessen the patient's trust of the caregiver's diagnostic and treatment recommendations. ${ }^{191}$

185. John E. Wennberg, Understanding Geographical Variations in Health Care Delivery, 340 NEW. ENG. J. MED. 52 (1999).

186. M. Gregg Bloche, Medical Care and the Enigma of Efficiency (Georgetown U. Law Center 1999 Working Paper Series Law Bus. \& Econs., Working Paper No. 184275, 1999).

187. Bloche, supra note 24 , at 106.

188. Id.

189. Roberto Bernabei et al., Management of Pain in Elderly Patients with Cancer, 279 J. AM. MED. Ass'N 1877 (1998). The study found that relative to White patients, after adjusting for language differences, African American patients were $63 \%$ more likely to go untreated for pain and were significantly less likely to have their complaints of pain reported. Id.

190. Id.

191. Bloche, supra note 24 , at 105. 


\section{Summary}

Even in the absence of any overt discriminatory motives, physicians' race-related implicit attitudes and implicit stereotypes likely influence their judgments in making discretionary medical decisions. There is growing evidence that this sort of implicit cognitive bias contributes to racial disparities in medical treatment decisions. Implicit attitudes and implicit stereotypes exist even in individuals who genuinely consider themselves to be unprejudiced, and both types of implicit cognitive bias can significantly influence the patient-caregiver relationship. Negative implicit attitudes can cause the caregiver to give off unfriendly behavioral cues that can lead to hostility and distrust in the patient. Implicit stereotypes can create unconscious expectations that significantly influence the caregiver's judgments in diagnosing and treating patients. Moreover, the interaction between physicians and patients might serve to heighten the effects of implicit cognitive bias: the physician's negative attitudes and stereotypes might create distrust and hostility on the part of the patient which in turn might adversely affect the caregiver's ability and motivation to give effective care.

\section{III}

\section{Existing Legal Safeguards that Might Be Used to Protect Against Discrimination in Medical Care}

Part II discussed the extent to which psychological variables can help explain racial disparities in medical health care. I proposed that the operation of implicit cognitive bias may be a significant contributing factor in the differential treatment of African Americans by medical caregivers. In this Part I examine whether the American legal system might reinforce the problem of disparities in health care by failing to adequately address this implicit form of discrimination. I analyze three possible avenues of legal redress-Title VI of the Civil Rights Act of $1964,{ }^{192}$ medical tort law, and the Emergency Medical Treatment and Active Labor Act ("EMTALA")and examine their potential to combat unconscious discrimination within the medical heath care system.

\section{A. Title VI}

Title VI of the Civil Rights Act of 1964 prohibits recipients of federal funds from discriminating on the basis of race, ethnicity, or national origin. ${ }^{193}$ Through enforcement by the DHHS, Title VI has helped eliminate discriminatory practices such as denial of admitting privileges to African American physicians, refusal to admit patients who are not cared for by attending physicians with staff privileges, high prepayment requirements

192. 42 U.S.C. $\$ 2000 d(2000)$.

193. Id. 
for African American patients, and discriminatory routing of ambulances. ${ }^{194}$ Moreover, Title VI's coverage of entities that receive "federal assistance" includes all hospitals that receive Medicare or Medicaid payments, making its potential reach remarkably broad. ${ }^{195}$

However, while Title VI has been successful in protecting against intentional discrimination within the health care setting, it is ill-suited in its current form to battle the more subtle problem of racial disparities in medical treatment that are caused by caregivers' implicit cognitive bias. ${ }^{196}$ Title VI provides two separate avenues for redress. The first is through section 601 , Title VI's disparate-treatment provision, which states that "[n]o person in the United States shall, on the ground of race, color, or national origin, be excluded from participation in, be denied the benefits of, or be subjected to discrimination under any program or activity receiving Federal financial assistance." 197 The Supreme Court has established that section 601 prohibits only explicit, intentional discrimination, ${ }^{198}$ which makes the section inapplicable to cases in which disparate treatment is caused by inplicit cognitive bias.

The second avenue for redress provided by Title VI is through section 602 , which authorizes federal agencies to "effectuate the provisions of [section 601] ... by issuing rules, regulations, or orders of general applicability." 199 The Supreme Court has not expressly held that section 602 prohibits only intentional discrimination, ${ }^{200}$ and indeed most federal agencies have adopted regulations pursuant to section 602 that bar the use of federal funds for programs that have a disparate impact on minorities. ${ }^{201}$ However, the Supreme Court's recent ruling in Alexander v. Sandoval severely limits the scope of section 602 and greatly limits any ability it previously might have had to protect against racial disparities in medical treatment. ${ }^{202}$

194. David B. Smith, Health Care Divided: Race and Healing a Nation 16-21 (1999). In these cases, the DHHS has compelled such measures as revision of requirements for staff privileges, elimination of prepayment requirements, and changes in ambulance routes. See Sara Rosenbaum et al., U.S. Civil Rights Policy and Access to Health Care by Minority Americans: Implications for a Changing Health Care System, 57 MEd. CARE REs. \& REv. 236, 247 (Supp. 1, 2000).

195. See Watson, supra note 10 , at 214.

196. Id. at $218-19$.

197. 42 U.S.C. $\$ 2000 \mathrm{~d}(2000)$.

198. See Alexander v. Sandoval, 532 U.S. 275, 280-81 (2001) (citing the Court's decisions in Guardians Assn. v. Civil Serv. Comm'n of New York City, 463 U.S. 582 (1983), and Alexander v. Choate, 469 U.S. 287 (1985), for the proposition that section 601 "prohibits only intentional discrimination").

199. 42 U.S.C. $\$ 2000 d-1(2000)$.

200. Sandoval, 532 U.S. at 281-82.

201. Charles F. Abernathy, Title VI and the Constitution: A Regulatory Model for Defining "Discrimination", 70 GEo. L.J. 1, 1 n.2 (1981).

202. 532 U.S. 275 (2001). 
At issue in Sandoval were regulations (promulgated by the U.S. Department of Justice ("DOJ") pursuant to section 602) that prohibited recipients of funding from "utiliz[ing] criteria or methods of admimistration which have the effect of subjecting individuals to discrimination because of their race, color, or national origin.."203 After failing her driver's license exam, plaintiff Martha Sandoval brought a class action suit against the Alabama State Department of Public Safety, arguing that the Department's policy of administering driver's license tests only in English violated the DOJ section 602 regulations. ${ }^{204} \mathrm{~A}$ federal district court in Alabama found that the English-only policy was invalid under Title VI because it had the effect of discriminating on the basis of national origin and had no substantial justification. ${ }^{205}$ The Eleventh Circuit affirmed, ${ }^{206}$ but the Supreme Court reversed, holding that Title VI does not create a private cause of action to enforce regulations promulgated pursuant to section $602 .{ }^{207}$

Writing for the Court, Justice Scalia began his analysis by offering three initial propositions concerning Title VI. First, private individuals may sue to enforce section 601 of Title VI and obtain both injunctive relief and damages. ${ }^{208}$ Second, section 601 prohibits only intentional discrimination..$^{209}$ Third, the Court assumed for the purposes of deciding the case that the DOJ regulations validly prohibited practices with a disparate impact on racial groups, even though it recognized that such activities are permissible under section $601 .^{210}$

The Court then noted that because the DOJ regulations were promulgated under section 602 , not under section 601 , any private right to enforce the DOJ regulations would have to come from "the independent force of 602."211 Examining the language of Title VI, the Court distinguished section 602 from section 601, stating that while private individuals may sue to enforce section 601 and obtain both injunctive relief and damages, ${ }^{212}$ the same was not true for section 602 . Focusing narrowly on section 602 , the Court found no rights-creating language, stating, "[s]o far as we can tell, this authorizing portion of $\S 602$ reveals no congressional intent to create a private right of action." 213

\footnotetext{
203. 28 C.F.R. $\S 42.104(b)(2)(1999)$.

204. Sandoval, 532 U.S. at 279.

205. Sandoval v. Hagan, 7 F. Supp. 2d 1234, 1249 (M.D. Ala. 1998).

206. Sandoval v. Hagan, 197 F.3d 484, 511 (11th Cir. 1999).

207. Sandoval, 532 U.S. at 293.

208. Id. at 279-80.

209. Id.

210. Id.

211. Id. at 286.

212. See Cannon v. Univ. of Chi., 441 U.S. 677 (1979).

213. Sandoval, 532 U.S. at 289.
} 
When combined with the Court's prior decisions holding that section 601 prohibits only "intentional discrimination," 214 Sandoval effectively precludes private claims that allege racial disparities in clinical treatment. Given that racial disparities in medical treatment rarely occur as a result of overt, intentional discrimination by physicians, ${ }^{215}$ minority patients are unlikely to have a cause of action to enforce section 601 . Furthermore, after Sandoval held that patients do not have a cause of action to enforce disparate-impact regulations, minority patients are severely restricted in challenges of medical care facility policies that are on their face neutral but have a discriminatory effect.

After Sandoval, section 602 disparate-impact regulations can be enforced only by administrative remedies, such as the revocation of federal funding like Medicaid and Medicare contributions for the health care facility at issue. Because such administrative remedies would adversely affect patients as much as physicians or hospitals, this does not seem to be an appropriate course of action. In addition, Sandoval effectively turns enforcement of disparate-impact regulations from a judicial process into a political process. This result will render section 602 toothless, given that the groups most likely to seek enforcement of the regulations do not enjoy the same access to the political process as do other groups. ${ }^{216}$

\section{B. Medical Tort Law}

Whereas medical malpractice law requires a unitary level of care, regardless of health insurance status or ability to pay, ${ }^{217}$ tort doctrine generally defers to physician standards of care. And disparities resulting from clinical discretion tend to fall within the bounds of generally accepted clinical variation. ${ }^{218}$ Therefore, so long as a defendant has not acted far outside the bounds of generally accepted standards, he or she can easily turn a suit stemming from racial disparity in medical treatment into a dispute over the proper standard of "reasonable care." Such disputes disfavor plaintiffs since the burden of proof is difficult to establish. ${ }^{219}$ Moreover, plaintiffs would have a difficult time proving causation-in-fact absent well maintained data concerning the efficiency of alternative approaches that would resolve racial disparity in clinical outcomes. ${ }^{220}$ Thus, bringing medical tort

214. Id. at 280 (citing Regents of Univ. of Cal. v. Bakke, 438 U.S. 265 (1978)).

215. See discussion supra Part II.

216. See, e.g., John H. Ely, Democracy and Distrust: A TheORY OF JUdicial Review 17279 (1980); Lani Guinier, The Tyranny of the Majority: Fundamental Fairness in REPRESENTATIVE DEMOCRACY 102-05 (1994).

217. See, e.g., Mark A. Hall, Making Medical. Spending Decisions: The Law, Ethics, and ECONOMICS OF RATIONING MECHANISMS 213-15 (1997).

218. Bloche, supra note 24 , at 108-09.

219. Id.

220. Id. 
law claims is a rather uninviting course of action for individuals seeking redress for racial disparities in medical treatment.

\section{The Emergency Medical Treatment and Active Labor Act of 1986}

In 1986, Congress enacted EMTALA, ${ }^{221}$ known as the "patient dumping" statute, to ensure that poor and uninsured patients receive at least the minimum standard of emergency care and are not turned away or prematurely transferred to another hospital simply because of their inability to pay. ${ }^{22}$ EMTALA applies to all hospitals that receive federal funding through Medicare and Medicaid programs. It provides that if an individual arrives at an emergency room requesting treatment, the hospital must provide an "appropriate medical screening examination" regardless of the individual's ability to pay. ${ }^{223}$ If after the screening the hospital determines that the patient has an emergency medical condition, the hospital then must provide medical treatment to stabilize the patient's condition prior to discharging the patient, unless the medical benefits of transferring the individual to another facility outweigh the risks to the individual. ${ }^{224}$ EMTALA's enforcement provisions subject a violating hospital to: (1) a monetary penalty of up to fifty-thousand dollars per violation;;25 (2) a private cause of action against the hospital; ${ }^{226}$ and (3) any appropriate equitable relief. 227

In Roberts v. Galen of Virginia, Inc., the Supreme Court resolved a split among the circuits, holding that EMTALA cannot "reasonably be read to require an improper motive."228 Thus, Roberts opened the door for plaintiffs with claims based on unintentional racial disparity in medical treatment. Under Roberts, any patient may state a claim under EMTALA if he or she demonstrates that the hospital provided disparate treatment, instead of providing appropriate medical screening.

Given the Court's decision in Roberts, EMTALA may provide a better option than Title VI for plaintiffs' claims of disparate medical treatment. On the other hand, EMTALA has certain limitations. The restricted scope only applies to the narrow category of emergency medical care. Moreover, the question of whether the hospital conducted an appropriate medical screening remains the essential element of a claim, and several circuit courts have held that EMTALA's mandatory emergency screening examination need not meet national standards of care, but instead must

221. 42 U.S.C. $\$ 1395 d d$ (2000).

222. See H.R. ReP. No. 99-241, pt. 1, at 27 (1986).

223. 42 U.S.C. $\$ 1395 \mathrm{dd}(\mathrm{a})(2000)$.

224. Id.

225. Id. $\S 1395 \mathrm{dd}(\mathrm{d})(1)$.

226. Id. $\$ 1395 \mathrm{dd}(\mathrm{d})(2)$.

227. Id. $\$ 1395 \mathrm{dd}(\mathrm{d})(3)$.

228. 525 U.S. 249, 253 (1999). 
only comply with the screening hospital's regular practices. ${ }^{229}$ Plaintiffs must therefore look to physicians familiar with emergency room screening practices at the hospital that they intend to sue, which could lead to a "code of silence" problem that could be difficult for plaintiffs to navigate..$^{230}$

\section{Summary}

Currently, no existing legal frameworks applicable to the health care context provide any recourse to adequately redress unintentional racial disparities in medical treatment. While section 601 of Title VI confers a private right to enforce the statute, it does so only for cases of intentional discrimination. ${ }^{231}$ Furthermore, although a number of agency regulations promulgated under section 602 prohibit actions with unintended disparate impact on minorities, under the Supreme Court's recent decision in Sandoval, no private right exists that allows an individual to sue to enforce those regulations. ${ }^{232}$ Finally, medical tort law and EMTALA's limited antidumping provisions are both inadequate as sources for remedies for racial disparities in medical treatment. ${ }^{233}$

\section{IV}

\section{FINDiNg The Proper Legal Framework}

The first step in addressing racial disparities in medical treatment would be for Congress to amend Title VI, thereby conferring a private right to enforce disparate-impact regulations promulgated pursuant to section $602 .{ }^{234}$ According to Justice Stevens in his dissent in Sandoval, the Sandoval majority greatly misconstrued Title VI in reading the section 602 disparate-impact regulations as inapplicable to section 601 and thereby precluding a private right of action under section $602 .^{235}$ Justice Stevens argued that "Section 601 does not stand in isolation, but rather as part of an integrated remedial scheme"236 and that section 602 thus empowers agencies to create prophylactic rules to "effectuate" the purposes of section $601 .^{237}$ He further stated that reading sections 601 and 602 as part of a whole "builds into the law flexibility, an ability to make nuanced

229. See, e.g., Jackson v. E. Bay Hosp., 246 F.3d 1248, 1255 (9th Cir. 2000); Summers v. Baptist Med. Ctr. Arkadelphia, 91 F.3d 1132, 1137 (8th Cir. 1996); Baber v. Hosp. Corp. of Am., 977 F.2d 872, 878 (4th Cir. 1992).

230. Bloche, supra note 24 , at 110 .

231. Alexander v. Sandoval, 532 U.S. 275, 280 (2001); see also Regents of Univ. of Cal. v. Bakke, 438 U.S. 265 (1978).

232. Sandoval, 532 U.S. at 293.

233. See supra Parts III.B \& 111.C.

234. See Tomas E. Perez, The Civil Rights Dimension of Racial and Ethnic Disparities in Health Status, in UNeQual TREATMENT, supra note 28, at 412-13.

235. Sandoval, 532 U.S. at 304 (2001) (Stevens, J., dissenting).

236. Id.

237. Id. at 305 . 
assessments of complex social realities, and an admirable willingness to credit the possibility of progress."238 Thus, Justice Stevens concluded that properly construed, Title VI incorporates the rights-creating language of section 601 into section $602 .{ }^{239}$

If Congress were to amend Title VI and effectively overrule Sandoval, individuals would have a private cause of action to challenge health care provider policies that have a disparate impact on minority groups. But such legislative action would be insufficient to fully address the problem. As discussed earlier, psychological factors can color physicians' clinical decisions and likely act as a major cause of racial disparities in medical treatment decisions. ${ }^{240}$ Thus, even if individuals could eradicate formal hospital policies that have a disparate impact on minorities, racial disparities in health care would persist insofar as they are not caused by any formal policies but rather are the result of implicit cognitive biases that skew physicians' clinical treatment decisions. This differential treatment is properly the subject of a private disparate-treatment cause of action, not the type of disparate-impact claim at issue in Sandoval. But given that implicit coguitive biases are inherently subtle and nondeliberate, they would elude any action under the provisions of section 601, Title VI's current disparatetreatment provisions, which forbid only intentional discrimination. ${ }^{241}$ Therefore, reform to Title VI should not end with the legislative override of Sandoval; rather, Congress must also alter the current structure of Title VI's disparate-treatment provisions to make them applicable to unconscious forms of discrimination.

In searching for a model for such reform, one possible starting place is the disparate-treatment frameworks of Title VII of the Civil Rights Act of $1964^{242}$ and the ADEA. ${ }^{243}$ Employment-related decisions are similar in many ways to decisions in the health care context in that both types of decisions are informed by a multitude of factors and generally involve the exercise of discretion on the part of the decision maker. As such, employment-related decisions are subject to the influence of implicit biases in much the same way that I argue medical treatment decisions are. ${ }^{244} \mathrm{How}$ ever, Title VII and the ADEA are not limited by Title VI's requirement that disparate treatment be a result of intentional discrimination. Given this flexibility, I argue in this Part that, although recent case law seems to have limited the reach of Title VII, the basic frameworks of Title VII and the

238. Id. at 307 .

239. Id. at 306 .

240. See discussion supra Part II.B.2.

241. See supra Part III.A.; see also Watson, supra note 10, at 218-19.

242. 42 U.S.C. $\$ 2000 \mathrm{~d}(2000)$.

243. 29 U.S.C. $\$ 623(2000)$.

244. See Linda H. Krieger, The Content of Our Categories: A Cognitive Bias Approach to Discrimination and Equal Employment, 47 STAN. L. REv. I161 (1995). 
ADEA (which was modeled after Title VII) provide a solid starting point for addressing disparate treatment stemming from implicit cognitive bias.

\section{A. Title VII as a Guiding Framework}

\section{Title VII's Disparate-Treatment Models}

Section 703 of Title VII of the Civil Rights Act of 1964 prohibits private and public employers from failing or refusing to hire, discharging, or otherwise discriminating against any individual because of his or her race, color, religion, sex, or national origin. ${ }^{245}$ Disparate-treatment cases under Title VII can be divided into two separate analytical models: the pretext model and the mixed-motive model. This Section assesses the applicability of these two models to cases involving racially disparate medical care caused by implicit cognitive biases.

Under the pretext model of disparate treatment under section 703, first articulated in the Supreme Court's decision in McDonnell Douglas Corp. v. Green ${ }^{246}$ and later clarified in Texas Department of Community Affairs $v$. Burdine ${ }^{247}$ a plaintiff can establish a prima facie case of racial discrimination by showing that (1) he or she belongs to a racial minority, (2) he or she applied for the job and met its qualifications, (3) despite being qualified, the employer rejected the application, and (4) after his or her rejection, the position remained open, and the employer continued to seek applicants with similar qualifications. ${ }^{248}$ Once the plaintiff establishes a prima facie case, the burden shifts to the employer to articulate a legitinate nondiscriminatory reason for the rejection. ${ }^{249}$ If the employer can articulate such a reason, then the plaintiff bears the ultimate burden of proving that the proffered reason was not the "true reason" for the decision, but rather was a "pretext for discrimination." 250

The Supreine Court, in Price Waterhouse v. Hopkins, ${ }^{251}$ laid the foundations of the mixed-motive model of analysis for Title VII cases. The Price Waterhouse Court found that impermissible sex stereotyping influenced the defendant employer's decision to deny partnership to a female candidate, but the Court held that the defendant could nevertheless avoid liability if it could prove that it would have made the same employment decision irrespective of the plaintiff's gender. ${ }^{252}$ The Court recognized that "Title VII [was] meant to condemn even those decisions based on a mixture of legitimate and illegitimate considerations" and that Congress

\footnotetext{
245. 42 U.S.C. $\$ 2000 \mathrm{e}-2$ (a) (2000).

246. 411 U.S. $792(1973)$.

247. 450 U.S. 248 (1981).

248. McDonnell Douglas, 411 U.S. at 802.

249. Id.

250. Id. at 804 .

251. 490 U.S. 228 (1989).

252. Id.
} 
did not intend to require a plaintiff "to identify the precise causal role played by legitimate and illegitimate motivations." ${ }^{253}$ However, the Court emphasized the necessity that the illegitimate motives play a "substantial" role in the ultimate decision. Thus, under the mixed-motive model, the defendant can avoid liability by showing that legitimate motives were controlling and that any illegitimate motives were insubstantial. ${ }^{254}$

\section{Application of the Models to Cases Involving Implicit Cognitive Bias \\ a. The Role of Discriminatory Intent in Title VII Cases}

Under the McDonnell Douglas pretext model, although the plaintiff does not need to produce any actual evidence of discriminatory intent, the intent of the employer is not irrelevant; the plaintiff still ultimately bears the burden of proving actual discriminatory intent, or animus, on the part of the employer. ${ }^{255}$ As the Seventh Circuit stated in Riordan v. Kempiers, the ultimate issue in a pretext model case is: "(1) Was [the employer's] proffered reason-a noninvidious reason-the true reason? (2) If not, was [plaintiff's] sex the real reason? Only if the first question was answered 'no' and the second 'yes' was [the employer] guilty of sex discrimination." 256 Thus, under the pretext model, an inference of discriminatory animus is drawn only upon a showing that the employer's proffered reasons were merely pretextual. ${ }^{257}$ This inferential process is based on a "presumption of invidiousness": once all legitimate reasons for an adverse employment action have been ruled out, the court is justified in assuming that the employer based its decision on an impermissible consideration such as race-assuming that people are rational and do not act in a totally arbitrary manner. ${ }^{258}$

It would be difficult if not impossible under the pretext model to prevail on a claim based on the type of disparate medical treatment discussed in this Comment. Under the pretext model, there is no consideration of implicit motives of any kind: at issue in a pretext model case is whether the plaintiff can show that the employer's proffered reasons were not the real reasons for the contested employment action. Whether implicit cognitive bias may have tainted the employer's decision-making process is therefore irrelevant because showing that implicit cognitive bias played a role in the contested employment decision would not amount to showing that the reason offered by the employer did not play a role and was mere pretext. In

253. Id. at 241.

254. Id.

255. Texas Dep't of Cmty. Affairs v. Burdine, 450 U.S. 248, 253 (1981) ("The ultimate burden of persuading the trier of fact that the defendant intentionally discriminated against the plaintiff remains at all times with the plaintiff.").

256. 831 F.2d 690, 696 (7th Cir. 1987).

257. See Burdine, 450 U.S. at 248; McDonnell Douglas Corp. v. Green, 411 U.S. 792, 804 (1973).

258. Furnco Constr. Corp. v. Waters, 438 U.S. 567 (1978). 
other words, the pretext model essentially requires conscious, intentional discrimination and therefore evidence of implicit cognitive bias is irrelevant.

Mixed-motive analysis as set forth in Price Waterhouse, on the other hand, initially seems to allow for the determination of liability based on the implicit cognitive bias of the employer. In Price Waterhouse, a plurality of the Court ${ }^{259}$ clarified that an employment decision based on both genderrelated and legitimate factors is prohibited under Title VII. ${ }^{260}$ Thus, on its face, Price Waterhouse seems to imply that in a mixed-motive model case, a plaintiff need only show that illegitimate motives played a role in the contested employment decision-not that illegitimate motives were the only motives at work. In other words, unlike in a pretext case, the plaintiff in a mixed-motive model case would not need to show that the reasons offered by the employer played no role in the decision. ${ }^{261}$ As the Price Waterhouse Court stated, "[w]here a decision was the product of a mixture of legitimate and illegitimate motives ... it simply makes no sense to ask whether the legitimate reason was the true reason for the decision."262

Mixed-motive analysis therefore appears to open the door for claims in which implicit cognitive bias influenced the contested employment decision by coloring the decision-making process. Indeed, the role of genderbased stereotypes was at issue in Price Waterhouse itself. ${ }^{263}$ In Price Waterhouse, the lower court found that the defendant had impermissibly discriminated against plaintiff Hopkins because sex stereotyping had tainted the partnership selection process. ${ }^{264}$ In making its determination, the lower court relied in part on the testimony of Dr. Susan Fiske, a social psychology professor, who testified at trial that some of the comments made by Price Waterhouse partners during the selection process were likely the product of sex stereotyping. ${ }^{265}$ Moreover, the Price Waterhouse Court seemed explicitly to leave open the possibility that even a lesser showing of impermissible stereotyping than established by Hopkins might suffice to establish liability for an employer. The Court stated that "stereotyped remarks can certainly be evidence that gender played a part"266 and that

[b]y focusing on Hopkins' specific proof . . . we do not suggest a limitation on the possible ways of proving that stereotyping played

259. Justices Marshall, Blackmun, and Stevens joined Justice Brennan's plurality opinion. Justices O'Connor and White wrote separate concurring opinions. Justices Kennedy, Rehnquist, and Scalia dissented.

260. Price Waterhouse v. Hopkins, 490 U.S. $228,240-41$ (1989).

261. The employer then has the burden of showing that it "would have made the same decision even if it had not allowed [illegitimate motives] to play such a role." Id. at 244-45.

262. Id. at 247 (internal quotations omitted).

263. Id. at 228.

264. Id. at 251 .

265. Id. at 255 .

266. Id. at 251-52. 
a motivating role in an employment decision, and we refrain from deciding here which specific facts, "standing alone," would or would not establish a plaintiff's case, since such a decision is unnecessary in this case. ${ }^{267}$

Thus, at least on its face, Price Waterhouse seems to allow for the possibility that evidence of impermissible stereotyping alone may be enough to establish liability in a mixed-motive model case, potentially allowing for disparate-treatment claims based on a decision maker's implicit cognitive biases.

\section{b. The "Direct" Evidence Requirement}

Upon closer examination, however, the mixed-motive model likely does not, under Price Waterhouse, stretch far enough to cover unconscious discrimination. In his plurality opinion in Price Waterhouse, Justice Brennan states that a plaintiff can prevail by showing that group status "played a motivating part" in the employer's decision, ${ }^{268}$ which seems to allow for claims alleging implicit cognitive bias. However, it is not entirely clear whether by "playing a motivating part," he meant that the group status must merely somehow influence the employer's decision or that it must be consciously included in the employer's decision-making process. ${ }^{269}$ There is at least some evidence that Justice Brennan had the latter in mind. Earlier in the opinion, he stated:

In saying that gender played a motivating part in an employment decision, we mean that, if we asked the employer at the moment of the decision what its reasons were and if we received a truthful response, one of those reasons would be that the applicant of employee was a woman. ${ }^{270}$

Thus, it appears that under Justice Brennan's formulation, the decision maker must have some introspective access to the illegitimate motives at work, which would likely rule out implicit cognitive bias as a basis for a valid claim. Moreover, even if Justice Brennan's notion of "played a motivating role" would support claims of unintentional bias, it might not make a difference since the opinion did not command a majority of Justices on the Court. Indeed, in the aftermath of Price Waterhouse, Justice O'Connor's concurring opinion, not Justice Brennan's plurality opinion, seems to be the determinative factor.

In her concurring opinion, Justice O'Connor more explicitly underscored the need for a showing of conscious discriminatory intent, arguing that Justice Brennan went too far in holding that the burden shifts when " $a$

267. Id.

268. Id. at 258 ,

269. Krieger, supra note 244, at 1172.

270. Price Waterhouse, 490 U.S. at 250. 
decisional process is 'tainted' by awareness of sex or race in any way.",271 Justice O'Connor further stated, "In my view, in order to justify shifting the burden on the issue of causation to the defendant, a disparate-treatment plaintiff must show by direct evidence that an illegitimate criterion was a substantial factor in the decision." 272 She noted that any evidence of illegitimate motives must be somehow connected to the employment decision. For example, she stated that statements by the employer, however discriminatory they may be, constitute only "stray remarks" that do not reach the level of "direct evidence" unless they are somehow connected to the employer's decision-making process. ${ }^{273}$

Since Price Waterhouse, lower courts have focused on Justice O'Connor's "direct evidence" language as the key determinant of whether a case is to be analyzed as a pretext or mixed-motive model case. ${ }^{274} \mathrm{~A}$ number of courts have interpreted "direct evidence" as requiring an extremely close connection between the evidence and the alleged discriminatory decision. ${ }^{275}$

For example, the Tenth Circuit, in Shorter v. ICG Holdings, defined direct evidence as "evidence, which if believed, proves [the] existence of [a] fact in issue without inference or presumption." 276 Under this definition, a plaintiff must show more than mere bias or stereotyping on the part of the employer; the plaintiff must show that the bias or stereotyping is connected to the contested employment decision. ${ }^{277}$ Thus, in Shorter, the court held that evidence showing that the employer referred to Shorter as an "incompetent nigger" several days after firing her was not direct

271. Id. at 276 (O'Connor, J., concurring).

272. Id. In his concurring opinion, Justice White did not mention a requirement that the evidence be "direct." He agreed with Justice O'Connor that, for a plaintiff to prevail, the evidence would have to show that the illegitimate criterion was a substantial factor in the employer's decision. Id. at 258-61 (White, J., concurring).

273. Id. at 277 (O'Connor, J., concurring).

274. See, e.g., Shorter v. ICG Holdings, Inc., 188 F.3d 1204, 1208 n.4 (10th Cir. 1999) ("Generally, a mixed motives analysis only applies once a plaintiff has established direct evidence of discrimination."); Randle v. LaSalle Telecommnnications, Inc., 876 F.2d 563, 569 (7th Cir. 1989) (noting that "the decision in Hopkins makes it clear that a case involving an initial offer of direct evidence of discrimination is quite distinct from one in which the plaintiff must rely upon the indirect method of proof established in McDonnell Douglas").

275. See, e.g., McKnight v. Kimberly Clark Corp., 149 F.3d 1125, 1129 (10th Cir. 1998) ("In order to rely on [allegedly discriminatory statements], [the employee] must show that they were made by a decision maker, and that there was a nexus between the discriminatory statements and the decision to terminate."); see also Shorter, 188 F.3d 1204; Indurante v. Local 75, Int'l Bd. of Teamsters, 160 F.3d 364 (7th Cir. 1998); Harris v. Shelby County Bd. of Educ., 99 F.3d 1078 (11th Cir. 1996); Randle, 876 F.2d 563. Some courts, however, have required less of a direct connection between the evidence and the alleged discriminatory decision. Compare Deenen v. Northwest Airlines, 132 F.3d 431 (8th Cir. 1998), Thomas v. Nat'1 Football League Players Ass'n, 131 F.3d 198 (D.C. Cir. 1997), and Ostrowski v. Atlantic Mutual Ins. Cos., 968 F.2d 171 (2d Cir. 1992), with Shorter, 188 F.3d 1204, Indurante, 160 F.3d 364, and Carter v. Three Springs Residential Treatment, 132 F.3d 635 (11th Cir. 1998).

276. Shorter, 188 F.3d at 1207.

277. Id. 
evidence because the comments were merely "statements of personal opinion" and because "the trier of fact would have to infer [the employer's] motive from her statements."278 Similarly, in Heim v. Utah, the Tenth Circuit held that an employer's statement, "[f]ucking women, I hate having fucking women in the office," did not constitute direct evidence of discrimination. ${ }^{279}$ The court stated:

Although the remark by [the employer] was certainly inappropriate and boorish, it was on its face a statement of [the employer's] personal opinion. The evidence does not show [that the employer] acted with discriminatory intent, only that he unprofessionally offered his private negative view of women during a display of bad temper at work. At best, it is only arguable that a discriminatory intent... can be inferred from the statement. This type of inferential statement is not "direct evidence" of discrimination satisfying plaintiff's burden. ${ }^{280}$

Other circuits have followed a similar approach. For example, in Carter v. Three Springs Residential Treatment, the Eleventh Circuit held that a manager's statements "identify[ing a personal] bias against blacks" and indicating that "she found [blacks] were difficult for her to trust or get along with" were not direct evidence because they were "susceptible to more than one interpretation" and did not directly relate to the employer's refusal to promote the employee. ${ }^{281}$ Similarly, the Seventh Circuit, in Hong v. Children's Memorial Hospital, held that neither a supervisor's statement to a Korean employee that she should "learn to speak English," when there was no evidence that the employee spoke any language other than English, nor racial slurs aimed at Koreans generally created an inference of discrimination absent evidence that the statements were related to the contested firing. ${ }^{282}$ And in Indurante v. Local 705, International Brotherhood of Teamsters, AFL-CIO, the plaintiff was fired from his job as a business agent with the defendant union, and several of the plaintiff's coworkers submitted affidavits alleging that after the firing, members of the management made a number of discriminatory comments, including: "all the Italians were going to be fired," "all the Italians were nothing but mobsters and gangsters," "the plans were to get rid of all the Italians," and "the days of the goombahs are over." 283 The court stated that it was "not obvious that the alleged statements [of the management] add[ed] up to direct proof of

278. Id. at $1206-08$.

279. 8 F.3d 1541, 1546 (10th Cir. 1993).

280. Id. at 1547 .

281. 132 F.3d 635, 642 (11th Cir. 1998).

282. 993 F.2d 1257, 1265-66 (7th Cir. 1993).

283. 160 F. 3d. 364, 366 (7th Cir. 1998). 
discriminatory intent"284 because it was not clear that the comments were "related to the employment decision in question." 285

In sum, most lower courts have essentially ignored the "played a motivating role" language in Justice Brennan's plurality opinion, focusing instead on the "direct evidence" requirenent in Justice O'Connor's concurring opinion.

\section{c. Implications for Claims Stemming from Unconscious Discrimination}

With Justice O'Connor's direct-evidence requirement, the mixedmotive mode of analysis ultimately may be no more favorable than the pretext model to the implicit cognitive bias and stereotyping clainis considered in this Comment. While the plain language of Justice Brennan's plurality opmion-requiring only that illegitiniate factors "played a notivating role"-possibly would support claims of unintentional discrimination, Justice O'Connor's opinion closes the door to that possibility. If courts, for instance, continue to follow the likes of Shorter, Heim, Carter, Hong, and Indurante and refuse to find that the explicit use of stereotypes and racial slurs suffice as direct evidence, then surely they will not find unconscious bias and stereotyping to be direct evidence either. Thus, with her "direct evidence" formulation, Justice O'Connor seenis to have raised the bar for determining what type of evidence will suffice in a mixed-nıotive model case. By requiring a close nexus between the evidence and the decision, the lower courts have interpreted the "direct evidence" language as essentially requiring evidence of a conscious connection between the employer's illegitimate motives and the employment decision. As Professor Linda Krieger noted:

Thus, the plurality opinion im Price Waterhouse frames causation not simply as an attempt to discern what actuated an employer's decision, but as an inquiry into the eniployer's conscious state of mind at the moment a decision was made. The distinction between nuotive and intent... appears to have escaped the Price Waterhouse Court. In both the plurality opinion and Justice O'Connor's infiuential concurrence, evidence that a decisionmaker holds stereotyped views of the plaintiff's group is deemed evidentially significant not in and of itself, but because it is assumed to betoken discriminatory animus. Nor is evidence of stereotyping itself sufficient to establish a Title VII violation-the plaintiff must prove the connection between stereotyping and discrininatory intent to prevail. ${ }^{286}$

284. Id. at 367.

285. Id. (citing Huff v. UARCO, Inc., 122 F.3d 374, 384 (7th Cir. 1997)).

286. Krieger, supra note 244, at 1172. 
According to Krieger, the Court in its terminology confused "motive" with "intent" and under the Price Waterhouse mixed-motive analysis, evidence of unconscious discrimmatory motives do not suffice to establish employer liability; rather, a plaintiff must prove actual discriminatory intent in order to prevail. ${ }^{287}$

The Price Waterhouse model of analysis, however, is not far from reaching unconscious disparate treatment. ${ }^{288}$ If courts focused on the Price Waterhouse plurality opinion's formulation-which creates liability where illegitimate factors "played a motivating role"-and either ignored or took a broad view of Justice O'Connor's "direct evidence" requirement, ${ }^{289}$ then the mixed-motive model potentially could encompass claims that implicit cognitive bias played a role in the decision-making process. Thus, the mixed-motive analysis, under a slightly different interpretation of Price Waterhouse, might still be useful in determining the proper legal framework to safeguard against racial disparities in medical treatment. In fact, the ADEA, which is based on Title VII, may better address unconscious discrimination simply because the courts have interpreted it differently. ${ }^{290}$

\section{B. The Age Discrimination in Employment Act}

The ADEA establishes two tiers of liability. Section $623^{291}$ sets the first tier, making it unlawful for an employer to "fail or refuse to hire or to discharge any individual or otherwise discriminate against any individual with respect to his compensation, terms, conditions, or privileges of employment, because of such individual's age."292 Violation of section 623, without any additional evidence of willfulness, constitutes nonwillful age discrimination and entitles plaintiffs to damages. ${ }^{293}$ By contrast, where the violation is found to be willful, section $626(\mathrm{~b})$ of the $\mathrm{ADEA}^{294}$ subjects the employer to double damages for violations of section $623 .{ }^{295}$

287. Id.

288. Id. at 1171.

289. Several courts have taken this approach. See Deneen v. Northwest Airlines, 132 F.3d 431, 436 (8th Cir. 1998) (finding that the plaintiff had introduced direct evidence of pregnancy discrimination where her employer, who knew she was pregnant, required a note from her doctor before letting her return to work); Thomas v. Nat'l Football League Players Ass'n, 131 F.3d 198, 204 (D.C. Cir. 1997) (describing direct evidence as "relat[ing] to the question of discrimination in the particular employment decision, not to the mere existence of other, potentially unrelated, forms of discrimination in the workplace").

290. Id.

291. 29 U.S.C. $\$ 623(2000)$.

292. Burlew v. Eaton Corp., 869 F.2d 1063, 1064 (7th Cir. 1989).

293. Id.

294. 29 U.S.C. $\$ 626(b)(2000)$.

295. See Burlew, 869 F.2d at 1064. The Supreme Court has held that the standard for determining whether a violation of the statute was willful is whether "the employer knew or showed reckless distegard for the matter of whether its conduct was prohibited by the ADEA." Trans World Airlines, Inc. v. Thurston, 469 U.S. 111, 126 (I985); see also McLaughlin v. Richland Shoe Co., 486 U.S. 128 (1988). 
Although the ADEA was modeled after Title VII and the language of section 623(a) is identical to section 703(a) of Title VII, ${ }^{296}$ courts have interpreted section 623(a) as requiring only that an illegitimate motive "made a difference" or "played a part" in a decision-making process to find a nonwillful violation of the statute. ${ }^{297}$ Thus, the courts have interpreted section 623(a) in Price Waterhouse mixed-motive analysis language, but in some cases they have softened-or perhaps omitted - any additional requirement that the plaintiff show direct evidence of discriminatory intent for a finding of nonwillful age discrimination. ${ }^{298}$ Consider the following language froin the Seventh Circuit's opinion in Burlew v. Eaton Corp.:

This standard-that age was a determining factor-does not in itself require a finding as to defendant's state of mind, for in law there is a distinction between motive and intent. "Motive is what prompts a person to act, or fail to act. Intent refers only to the state of mind with which the act is done or omitted." [C]ongress, in our opmion, intended that liability under the ADEA could be established without any showing as to the defendant's state of mind." 299

In distinguishing between motive and intent, the Burlew court relied upon the observation made by the court in Syvock v. Milwaukee Boiler Manufacturing $C o$. that age discrimination may be "unconsciously motivated," as it might "simply arise from an unconscious application of stereotyped notions of ability rather than from a deliberate desire to remove older employees from the workforce." ${ }^{300}$ Several courts have since reiterated the same distinction. ${ }^{301}$

296. 42 U.S.C. $\$ 2000 \mathrm{e}-2$ (a) (2000). Section 703(a) states that it is an unlawful employment practice for an employer "to fail or refuse to hire or to discharge any mdividual, or otherwise to discriminate against any individual with respect to his compensation, terms, conditions, or privileges of employment, because of such individual's race, color, religion, sex, or national origin." Id.

297. See Lowe v. Commack Union Free Sch. Dist., 886 F.2d 1364, 1376 (2d Cir. 1989).

298. See Krieger, supra note 244, at 1170.

299. $\$ 69$ F.2d at 1066.

300. 665 F.2d 149, 154-55 (7th Cir. 1981). The Syvock court's tracing of legislative history of the ADEA in making this statement might provide some explanation of why unconscious motives were read into the ADEA even though they had not been read into Title VII. The court stated that the congressional framers thought that nonwillful discrimination directed towards an individual was quite possible:

Age discrimination is not the same as the insidious discrimination based on race or creed prejudices and bigotry. Those discriminations result in nonemployment because of feelings about a person entirely unrelated to his ability to do a job. This is hardly a problem for the older job-seeker. Discrimination arises for him because of assumptions that are made about the effects of age on performance. As a general rule, ability is ageless.

Id. at 155 (quoting the remarks of Rep. Burke in 113 CoNG. Rec. 34,742 (1967)).

301. See, e.g., EEOC v. Century Broad. Corp., 957 F.2d 1446, 1466 (7th Cir. 1992) (Manion, J., dissenting) ("To determine whether an ADEA violation was willful, we should ask: Was the employer's conduct consciously motivated by age, or was it the unconscious application of a stereotype about older workers' abilities?"); Trent v. AT\&T Techs., 716 F. Supp. 1461, 1465 (N.D. Ga. 1989) ("This court holds that it is within the province of the jury, if properly instructed, to find non-willful 
Thus, under the ADEA, unlike under Title VIl, it may be possible for a plaintiff to prevail despite an inability to prove actual discriminatory animus on the part of the employer. ${ }^{302}$ Moreover, the ADEA section 623(a) framework is simply a slight adaptation of the framework set forth in Price Waterhouse. The only difference is that in the context of Title VII the "motive" in mixed-motive has been interpreted by most courts as simply meaning "intention," whereas in the context of the ADEA, a discriminatory "motive," in the true sense of the term, can lead to employer liability. Both the frameworks of the ADEA and Title VII (as laid out in Price Waterhouse but under a slightly broader interpretation) appear to encompass disparate-treatment claims that are based on discrimination stemming from implicit cognitive bias. Thus, legislators could use both frameworks as models for the Title VI reform necessary to address the racial disparities in medical treatment caused by implicit, unintentional bias.

\section{Summary}

Although Title VII's pretext model of analysis seems unworkable as a model for handling disparate-treatment claims based on unintentional discrimination, the general framework of the Title VIl mixed-motive model appears to be well-suited for such claims. Indeed Justice Brennan's plurality opinion may allow, at least by its plain terms, claims of unintentional discrimination, as it requires only that a plaintiff show that illegitimate factors played a motivating role in the employer's decision. But most lower courts have incorporated Justice O'Connor's "direct evidence" requirement into the mixed-motive analysis. And her "direct evidence" requirement effectively requires proof of intentional discrimination on the part of the employer. As the ADEA case law has shown, however, this requirement is not essential to the viability of the mixed-motive analysis, and without it, the mixed-motive framework adequately encompasses disparate-treatment claims stemming from unintentional discrimination.

\section{$\mathrm{V}$ \\ CONCLUSIONS AND RECOMMENDATIONS}

Given the prevalence of racial disparities in medical treatment and the mounting evidence that such disparities are at least in part the product of implicit cognitive biases on the part of health care providers, it is paramount that the legal system provide some form of recourse for minority patients who receive disparate medical treatment due to unintentional discrimination. There currently are no viable avenues for remedy within the legal system for minority patients who receive disparate medical treatment

discrimination. Stereotyped assumptions are often hard to detect because they are so intimately related to other judgments about employment.").

302. See Krieger, supra note 244 , at 1170. 
resulting from such discrimination. Given that most hospitals receive federal funding in the form of Medicaid or Medicare, Title VI, with its prohibition on discrimination by recipients of federal funds, seems to be the obvious place to turn for legal redress. But Title VI in its current form is inadequate to fully deal with the problem of racial disparities in health care and thus should be ainended to include disparate-treatment provisions that allow for claims based on unintentional discrimination.

As noted in the last Part, the first step of reform should be for Congress to effectively overrule the Supreme Court's decision in Sandoval by amending Title VI to explicitly provide a private right of action for disparate-impact claims. ${ }^{303}$ By doing so Congress would allow minority patients to challenge health care facility policies that are race-neutral on their face but have discriminatory effects in practice..$^{304}$ Such legislative action would help equalize access to health care facilities and combat racial and ethnic discrimination at the institutional level. ${ }^{305}$

As also noted above, however, overruling Sandoval legislatively would not be enough to address the problem of racial disparities in health care fully. If, as I contend here, racial disparities in medical treatment are in significant part caused by implicit cognitive bias on the part of the caregiver, Title VI's disparate-treatment provisions, which concern individual behaviors rather than policy-level forces, must be reworked as well. ${ }^{306}$ The general framework of Title VII's disparate-treatment provisions-which encompass claims of racially differential treatment that stem from unintentional discrimination-provides an obvious model for such reform. Thus, just as the ADEA was modeled after Title VII, Congress should amend Title VI to align its disparate-treatment provisions with those of Title VII.

However, Congress should not merely replicate the Title VII provisions. As recent case law has made clear, Title VII's ability to address unintentional discrimination adequately is a matter of judicial interpretation. While the "played a motivating role" language of the plurality opinion in Price Waterhouse on its face covers claims of unintended disparate treatment, recent case law indicates that this mode of analysis likely does not cover claims of unintentional or unconscious discrimination because courts' interpretation of Justice O'Counor's "direct evidence" language essentially imposes a requirement of conscious discriminatory intent. ${ }^{307}$ But such an interpretation is not essential to mixed-motive analysis. Indeed, as discussed above, the ADEA's two-tier disparate-treatment framework, which is inodeled after Title VII's mixed-motive framework but has been

303. See Perez, supra note 234 , at $412-13$.

304. Id.

305. Id.

306. See discussion supra Part IV.

307. See discussion supra Part IV.A.2.c. 
interpreted slightly differently by the courts, may provide a remedy for unintentional discrimination. ${ }^{308}$ Thus, in modeling Title VI after Title VII, Congress should include explicit provisions that ensure that it can be used as a private cause of action to challenge disparate-treatment claims stemming from unintentional discrimination. The amendments should, for example, follow along the same lines as Krieger's suggestions for a reinterpretation of Title VII:

To establish liability for disparate treatment discrimination, a Title VII plaintiff would simply be required to prove that his group status played a role in causing the employer's action or decision. Causation would no longer be equated with intentionality. The critical inquiry would be whether the applicant or employee's group status "made a difference" in the employer's action, not whether the decisionmaker intended that it made a difference. ${ }^{309}$

Title VI disparate-treatment liability would therefore be based on whether there is evidence that a patient's group status played a role in the medical caregiver's decisions. Unlike in Justice O'Connor's mixed-motive analysis, liability would not depend on the existence of "direct evidence" tied explicitly to the decision-making process. Thus, the provisions would cover claims in which there is evidence that implicit cognitive bias played a role in the caregiver's treatment decisions.

While implicit cognitive bias is by definition subtle and difficult to discern-and perhaps even completely invisible to the implicitly biased individual - it does, as discussed in Part II, have detectable effects on the implicitly biased individual's behavior. Thus, for example, evidence that the caregiver has repeatedly made stereotyped remarks about the patient's racial group (even "stray remarks" under Justice O'Connor's formulation), that the caregiver has a history of conflicts or poor relations with members of the group, or statistical information showing that the caregiver has repeatedly given disparate treatment to members of the group might all constitute evidence that the patient's race played a role in the decisions leading to the disparate treatment.

Another crucial feature of the Title VII and ADEA frameworks that should be incorporated into the Title VI framework is their burden-shifting structure. ${ }^{310}$ Once a patient can establish that a patient's group status played a role in the decisions leading to disparate treatment, the burden would shift to the caregiver to show that implicit cognitive bias did not make a difference in the treatment decision-making process. ${ }^{311}$ This

308. See discussion supra Part IV.B.

309. Krieger, supra note 244, at 1241.

310. See McDonneII Douglas Corp. v. Green, 450 U.S. 248 (1981); Texas Dep’t of Cmty. Affairs v. Burdine, 411 U.S. 792 (1973).

311. In Price Waterhouse, Justice Brennan noted that once the plaintiff shows that illegitimate factors played a motivating role in the defendant's dccision, the defendant can escape liability by 
burden-shifting creates a presumption against the caregiver that is crucial in the context of unintentional discrimination. As Professor Deborah Calloway has observed:

A presumption... can serve the purpose of forcing a correct decision that courts and juries are likely not to reach because of their personal prejudices and biases. Inferring discrimination is just such a situation and warrants exactly that treatment. Discrimination is rampant, but judges, academics and laypersons alike either underestimate its prevalence or believe that their group and not other groups are victimized. Under these circumstances, in a world in which most people are smart enough to avoid providing direct evidence of discriminatory intent, it is critical for the law to define a prima facie case which creates a presumption of discrimmation absent evidence to the contrary. ${ }^{312}$

Thus, allowing the burden of proof to shift to the defendant, thereby creating a presumption in favor of the plaintiff, makes a disparate-treatment claim based on unintentional discrimination more viable. Letting the burden of proof rest ultimately with the plaintiff would constitute an effective bar against claims of unintentional discrimination as seen in the context of medical tort law. ${ }^{313}$

While admittedly there are important differences between Title VI and Title VII ${ }^{314}$ legislators should not feel overly constrained by historical differences between the statutes in determining how to reshape Title VI to deal with racial disparities in medical care. Title VI was enacted to address specific societal problems regarding race-perhaps most prominently, racial segregation at the institutional level such as in schools and hospitalsand it has been successful in achieving nany of its initial aims. ${ }^{315}$ But, as I have argued, racial discrimination in society has not disappeared along with segregation; its form has merely changed. Thus, many of the racial probleins facing the health care system continue to exist below the conscious surface, with negative implicit racial attitudes and beliefs outlasting more explicit forms of racial prejudice. Moreover, while discrimination at the institutional level undoubtedly still exists (for example, as the disparate impact of facially race-neutral administrative policies), the discrimination

providing an affirmative defense that the illegitimate factors did not ultimately make a difference. Price Waterhouse v. Hopkins, 490 U.S. 228, 246-47 (1989).

312. Deborah A. Calloway, St. Mary's Honor Center v. Hicks: Questioning the Basic Assumption, 26 CONN. L. REv. 997, 1037 (1994).

313. See discussion supra Part III.B.

314. See Watson, supra note 10, at 971 (arguing that "[t]here are crucial structural and philosophical differences between the two statutes and the activities they regulate. These differences destroy any attempted analogy between Title VI and Title VII, and argue, instead, for an independent Title VI doctrine defining the defendant's burden of justification in a disproportionate adverse impact case").

315. See supra notes $192-96$ and accompanying text. 
resulting from implicit cognitive biases operates at the level of the individual. Thus, in order for Title VI to be effective in combating contemporary forms of prejudice and discrimination, it must be able to address harms caused by implicit, unintentional behavior by individuals.

A number of recent nonlegislative initiatives, programs, and studies have recognized the problem of racial disparities in health care and have proposed various plans to reduce such disparities. Some have even recognized the need to address the effects of implicit cognitive bias on medical treatment. ${ }^{316}$ For instance, in a radio address in $1998,{ }^{317}$ President Clinton announced his "Initiative on Race," which included the goal of eliminating racial disparities in six areas of health status by $2010 .{ }^{318}$ As part of the initiative, the National Institutes of Health ("NIH") developed its "Program of Action," which set a five-year plan for reducing racial disparities in health care. ${ }^{319}$ The NIH plan concerns three areas: research, research infrastructure, and public information and community outreach. ${ }^{320}$ Also in response to the presidential initiative, the DHHS set forth standards for "Culturally and Linguistically Appropriate Services" to help reduce differential treatment caused by language barriers and cultural differences. ${ }^{321} \mathrm{~A}$ number of states have joined in this effort by creating offices, commissions, councils, and advisory panels on minority health to address the problem of health disparities. $^{322}$

While such policy-level actions will undoubtedly play an integral and necessary role in attempting to eliminate racial disparities in health care, it is unlikely that they will be sufficient; they are not properly aimed at correcting the bias of the cognitive processes of individual medical caregivers. Insofar as implicit cognitive bias contributes to racial disparities in medical treatment, measures should be taken to directly counteract the biased cognitive processes. For example, some commentators suggest that "evidencebased" guidelines might give caregivers more concrete standards with which to decide on the most appropriate avenue of care, thereby reducing the discretion that provides an opening for implicit cognitive biases to influence decisions. ${ }^{323}$ In addition, some commentators have suggested that if

316. See UNEQUaL TREATMENT, supra note 28 , at 127-41.

317. See Nat'l Insts, of Health, Addressing Health Disparities: The NiH Program of ACTION, at http://healthdisparities.nih.gov/whatare.html.

318. Id. The six areas are infant mortality, cancer screening and management, cardiovascular disease, diabetes, HIV infection and AIDS, and immunizations. Id.

319. Nat'l Insts. of Health, Strategic Research Plan to Reduce and Ultimately Eliminate HEALTH Disparities (2000), available at http://www.nih.gov/abouthd strategicplan.pdf.

320. Id. at 14.

321. See UNEQUAL TREATMENT, supra note 28 , at 143.

322. Nat'l Conference of State Legislatures, Racial Disparities in Health, at http://www.ncsI.org/programs/health/disparity.htm (updated March 2002).

323. See Unequal Treatment, supra note 28 , at 13. 
the problems of implicit cognitive bias are taught at all levels of undergraduate and graduate medical training, caregivers will be more aware that such bias might lead to unintended differential outcomes. ${ }^{324}$

However, while direct in targeting individuals' implicit cognitive bias, these measures, like the policy-level measures, likely will fall short. Evidence-based guidelines might help to standardize procedures across individuals, but they will not be able to eliminate caregiver discretion altogether. Discretion is an inherent part of medical care, one that is necessary to deal with the particularities of situations. There will always be opportunities for differential treatment.

More importantly, measures that are directed at promoting the selfregulation of caregivers' implicit cognitive biases are effective only insofar as the individual is aware that he or she carries these biases. As discussed in Part II, implicit biases by definition are hidden, and they often conflict with explicit attitudes and beliefs, making recognition by an individual that he or she in particular has such biases difficult. Indeed, as one set of psychological researchers observed, individuals who hold implicit prejudices "do not see themselves as racist and, thus, perceive no need to change." 325 The researchers contended that "[c]hange would require, at a minimum, first becoming aware of their subtle biases," but that individuals with implicit biases "are not consciously aware of their conflicted reactions." 326 Moreover, the inability to recognize one's own implicit biases may be especially characteristic of medical caregivers. As one researcher noted, "the idea that racial/ethnic bias might be operative conflicts with most physicians' conscious commitment to anti-discriminatory principles, their views of their own behaviors, that of their peers and the institutions within which they work, and the ethical commitments of inedicine." 327 Thus, efforts aimed at educating individuals about the existence and effects of implicit cognitive biases alone will likely be insufficient to convince individuals that they themselves have such biases.

Research shows that merely being aware of one's implicit biases is not enough to counteract the biases; rather, one must be internally motivated to correct for implicit biases. ${ }^{328}$ While normative social pressures may be enough to cause one to change his or her explicit attitudes and beliefs, only personal, internal motivation will be sufficient to affect changes in implicit cognitive bias. ${ }^{329}$ Some commentators have suggested that an increase in medical care facilities' abilities to monitor care systematically

324. Id. at 236.

325. Devine et al., supra note 110, at 205.

326. Id.

327. H. Jack Geiger, Racial and Etlmic Disparities in Diagnosis and Treatment: A Review of the Evidence and a Consideration of Causes, in UNEQUAL TREATMENT, supra note 28, at 217.

328. See Devine et al., supra note 110 , at 208-12.

329. Id. 
and regularly may provide caregivers with more motivation to correct for implicit cognitive biases and provide equal care. ${ }^{330}$ This may be a partial solution, but it is unlikely to create the level of accountability required to force medical caregivers to recognize and to change their implicit tendencies and biases. The type of legislative amendments to Title VI that I recommend-creating a private right of action for disparate treatment based on unintentional discrimination-directly targets the individual caregiver and in doing so would likely provide the requisite level of accountability to cause changes in individual behavior.

There are admittedly a number of valid concerns that seem to weigh against imposing liability on caregivers for unintentional discrimination. One argument against imposing liability for unintentional discrimination in the context of medical care is that given the complexity of medical decision making-which rests on the interaction of multiple factors and which depends to a large extent on the caregiver having some flexibility and discretion-there are often legitimate reasons for differential treatment, even for situations that, on their face, appear similar. In other words, every medical situation in some sense is unique, and thus determining when patients are similarly situated is exceedingly difficult, if not impossible.

This argument, however, speaks to the question of whether there was in fact disparate treatment in a given case and to the difficulty of prevailing in a disparate-treatment case based on unintentional discrimination; it does not speak to the question of whether liability should ever be imposed. The fact that there are often legitimate reasons for differential treatment might mean that it may be easy for caregivers in certain cases to prevail by showing that the presence of discriminatory bias made no difference in the treatment decision. But the mere fact that differentiating legitimate reasons from illegitimate ones or determining when implicit cognitive bias played a significant role in medical decision making will in many cases be difficult should not automatically lead to the conclusion that courts will not be able to make such distinctions. Courts make difficult decisions regarding sophisticated decision-making processes all the time, and there is no reason to think that they would be unable to do so in this context as well.

One might also be inclined to argue that, to the extent the existence of implicit bias in some form or another is virtually universal, ${ }^{331}$ establishing liability for unintentional discrimination would be inherently unreasonable. Indeed, as I have discussed, implicit attitudes and stereotypes arise out of universal functions of human cognition necessary for navigating one's social environment. Krieger has written:

$[\mathrm{N}]$ ot only are many of the cognitive processes which cause discrimination automatic and beyond ordinary conscious

330. See UNEQUAL TrEatMENT, supra note 28, at 236.

331. See Krieger, supra note 244, at 1239-40. 
self-awareness, they are adaptive, indeed, essential to effective cognitive functioning. People will divide the natural and social environment into categories; they will use stereotypes, scripts, and schemas to interpret, encode, and retrieve information relevant to social judgnient. ... And because race, ethnicity, and gender have been made salient by our history and by observable patterns of economic, demographic, and political distribution, people will continue to categorize along those lines. ${ }^{332}$

Thus, if everyone has implicit cognitive biases, one might argue that imposing liability for the behavior that stems from such biases does not make sense.

That implicit cognitive biases are the result of universal cognitive processes, however, does not necessarily mean that a liability scheme based on such biases is unworkable. The fact that everybody has some implicit cognitive biases does not mean that everybody has the same types of implicit cognitive biases or is implicitly biased to the same degree. Indeed, there is firm empirical evidence that there is variance in the extent to which individuals hold negative implicit racial attitudes and stereotypes. ${ }^{333}$ Thus, the universality of implicit cognitive bias simply indicates that legislators should be careful in determining the level of implicit cognitive bias at which liability attaches. If they set that level significantly above the baseline level of implicit cognitive bias, then there would be no real danger that the type of disparate-treatment provisions that $I$ endorse could be applied to individuals across the board.

In determining the proper evidentiary framework for an amended Title VI, legislators should also take into consideration the extent to which psychological research may demonstrate that mdividuals can control and change their implicit cognitive biases. If individuals do not have control over or the ability to change their implicit cognitive biases, imposing liability for unintentional discrimination would effectively amount to strict liability. ${ }^{334}$ Although strong empirical evidence indicates that, im general, individuals can change or control their implicit cognitive biases when they are internally motivated to do $\mathrm{so}^{335}$-suggesting that at least some level of liability is warranted-legislators should allow courts to take into account the psychological research that identifies the more precise conditions affecting such controllability in determining in which particular circumstances liability would be appropriate.

Concerns about the universality and controllability of implicit biases should caution legislators to tailor amendments in a way that will allow

332. Id.

333. See KUNDA, supra note 146, at 325-36; Nosek et al., supra note 140, at 112.

334. See Amy L. Wax, Discrimination as Accident, 74 IND. L.J. 1129 (1999).

335. See Dovidio et al., supra note 120, at 191; Greenwald \& Banaji, supra note 117, at 18; KUNDA, supra note 146, at 361-65. 
courts to stay in line with the rapidly changing state of knowledge about the mechanisms underlying implicit cognitive bias. While the methods used to gauge individual differences in implicit cognitive bias are rapidly becoming more sophisticated ${ }^{336}$ and researchers continue identify new, effective strategies to counteract such bias, ${ }^{337}$ research in these areas is still in relative infancy. Thus, courts should be afforded some flexibility in deciding whether given what is known at the time about indicators and controllability of implicit cognitive bias, the type and amount of evidence present is enough to show that such bias played a role in the decision. As discussed in Part IV, Justice O'Connor's requirement that evidence be "direct" is too stringent because it bars claims of unintentional discrimination altogether, but below that, courts should be allowed to determine the sufficiency of evidence on a case-by-case basis. Setting a universal standard that is too lenient might result in overregulation, which in turn might restrict the discretion of medical caregivers in ways that could be harmful to patients. Thus, taking into account the current understanding of the psychological mechanisms underlying implicit coguitive bias is crucial in determining the proper statutory framework for combating unintentional discrimination.

The American Medical Association's Council on Ethical and Judicial Affairs noted in 1990 that "[d]isparities in treatment decisions may reflect the existence of subconscious bias... . The health care system, like all other elements of society, has not fully eradicated this prejudice." ${ }^{2338}$ More than a decade later this remains true. The problem of racial disparities in medical care continues to slip between the cracks of existing legal frameworks, and Congress must take affirmative steps to ensure movement toward racial equality in health care.

336. See Devine et al., supra note 110, at 207; Dovidio, supra note 113, at 833.

337. See Greenwald \& Banaji, supra note 117 at 19; Dovidio et al., supra note 120, at 191-92; KunDA, supra note 146 , at 380-385.

338. Council on Ethical and Judicial Affairs, Black-White Disparities in Health Care, $263 \mathrm{~J}$. AM. MED. Ass'N 2344 (1990). 